Prepared in cooperation with the Muskingum Watershed Conservancy District

\title{
Hydrologic and Hydraulic Analyses for the Black Fork Mohican River Basin in and near Shelby, Ohio
}

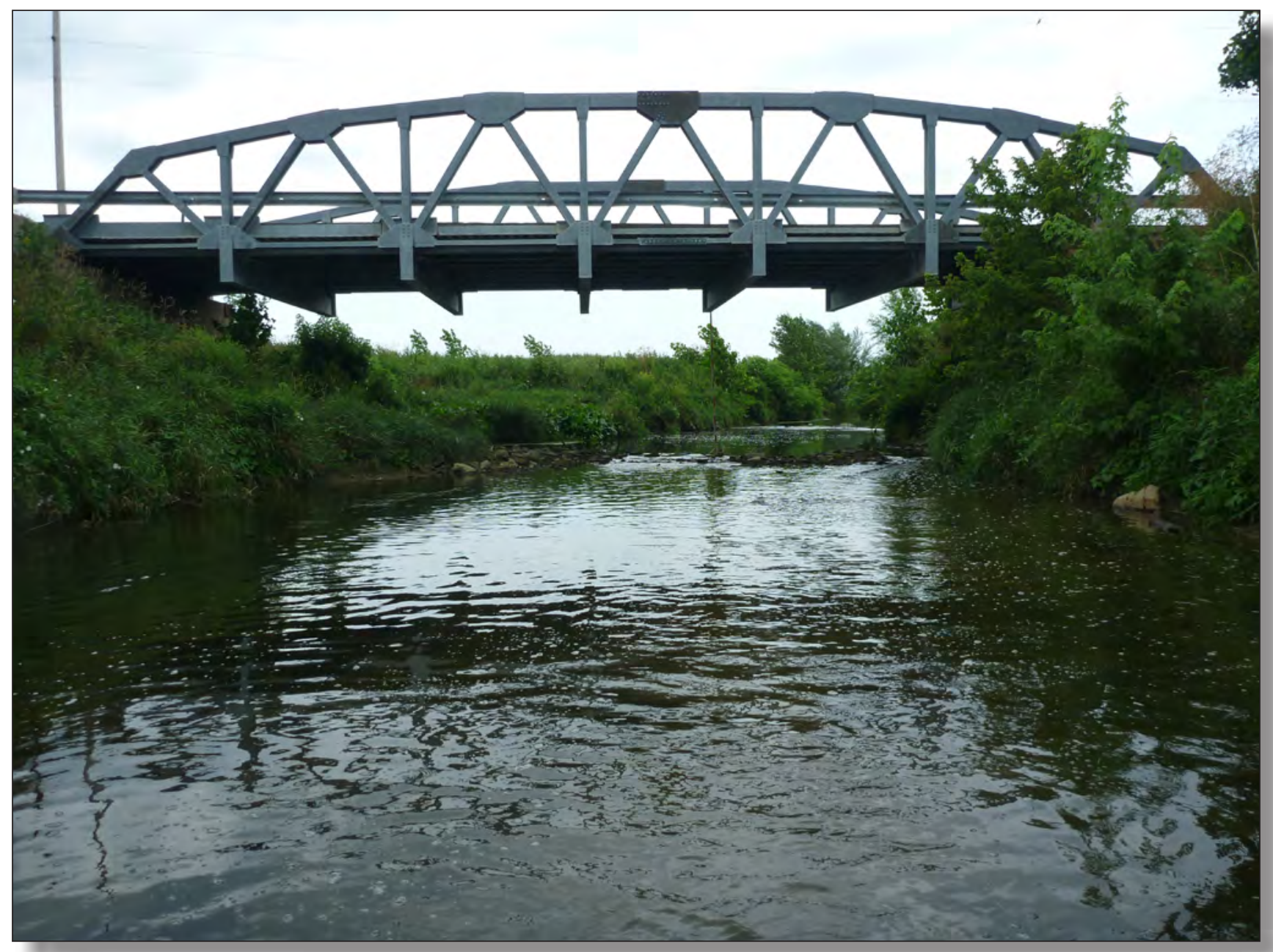

Scientific Investigations Report 2015-5187 
Cover: Steel-truss bridge on Plymouth-Springmill Road over the Black Fork Mohican River (looking north and downstream). Photo taken in 2012 by USGS personnel. 


\section{Hydrologic and Hydraulic Analyses for the Black Fork Mohican River Basin in and near Shelby, Ohio}

By Carrie A. Huitger, Chad J. Ostheimer, and G.F. Koltun

Prepared in cooperation with the Muskingum Watershed Conservancy District

Scientific Investigations Report 2015-5187 


\title{
U.S. Department of the Interior SALLY JEWELL, Secretary
}

\section{U.S. Geological Survey Suzette M. Kimball, Director}

\author{
U.S. Geological Survey, Reston, Virginia: 2016
}

For more information on the USGS - the Federal source for science about the Earth, its natural and living resources, natural hazards, and the environment—visit http://www.usgs.gov or call 1-888-ASK-USGS.

For an overview of USGS information products, including maps, imagery, and publications, visit http://store.usgs.gov/.

Any use of trade, firm, or product names is for descriptive purposes only and does not imply endorsement by the U.S. Government.

Although this information product, for the most part, is in the public domain, it also may contain copyrighted materials as noted in the text. Permission to reproduce copyrighted items must be secured from the copyright owner.

Suggested citation:

Huitger, C.A, Ostheimer, C.J., and Koltun, G.F., 2016, Hydrologic and hydraulic analyses for the Black Fork Mohican River Basin in and near Shelby, Ohio: U.S. Geological Survey Scientific Investigations Report 2015-5187, 39 p., 2 appendixes, http://dx.doi.org/10.3133/sir20155187.

ISSN 2328-0328 (online) 


\section{Contents}

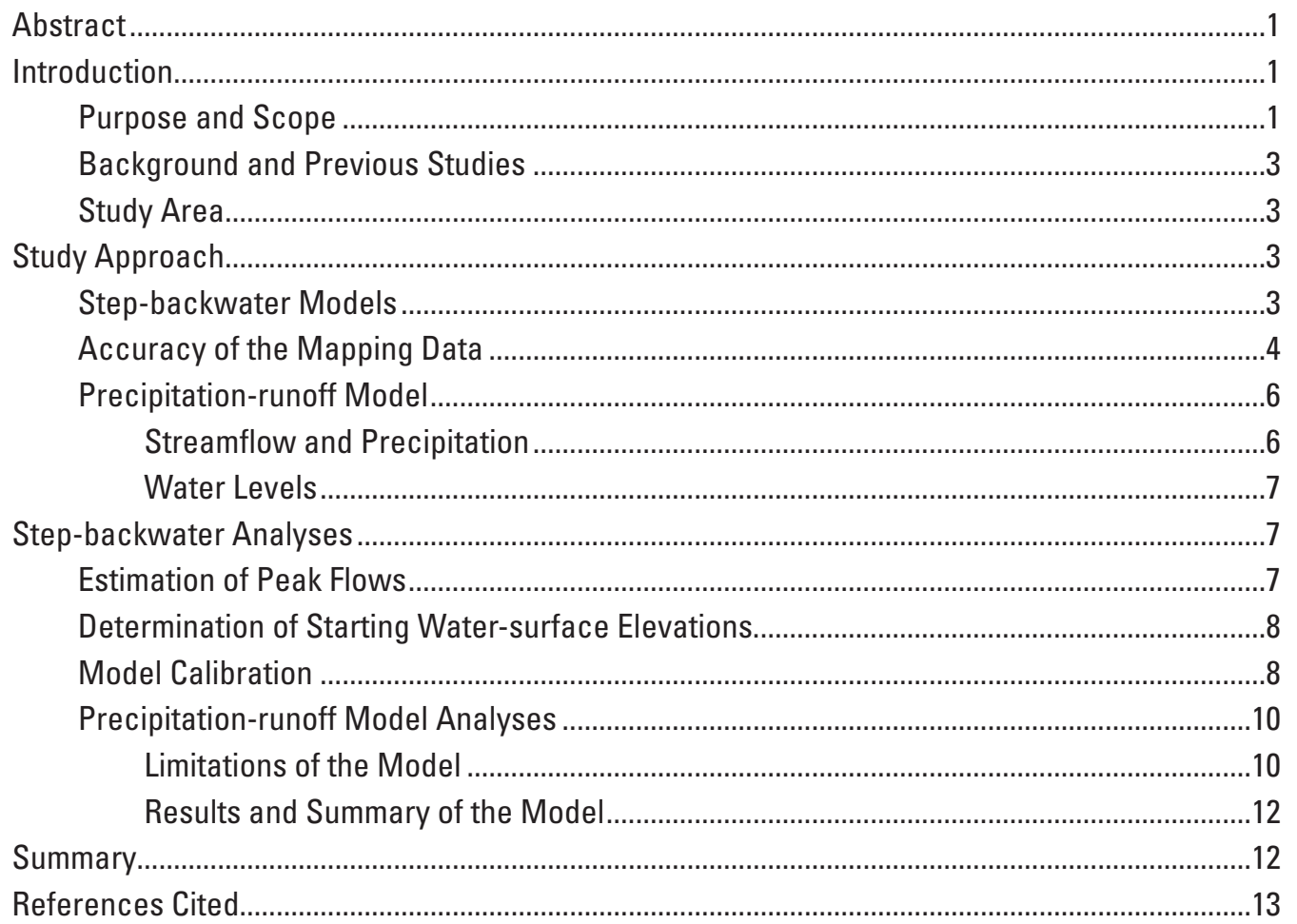

\section{Figures}

1. Map showing the study area within Richland County in and near Shelby, Ohio.

\section{Tables}

1. Hydraulic model limits for selected streams in and near Shelby, Ohio .............................4

2. Comparisons of published National Geodetic Survey benchmark coordinates and elevations to those surveyed by the U.S. Geological Survey.

3. Summary of the explanatory variable values used in the regression equations and the final 10-, 2-, 1-, and 0.2-percent annual exceedance probability flood-peak discharge estimates and locations for the selected streams in and near Shelby, Ohio .......8

4. Selected hydraulic parameters used for HEC-RAS steady-state models in and near Shelby, Ohio

5. Summary data from the Black Fork Mohican River at Shelby, Ohio streamflowgaging station 03129197, including the observed data from selected dates, estimates obtained using the HEC-HMS precipitation-runoff model, and the model performance statistics. 


\section{Appendixes}

Appendix 1. Tables showing HEC-RAS Output for Selected Stream reaches in and near Shelby, Ohio

[Appendix 1 may be downloaded as a separate file at http://dx.doi.org/10.3133/sir2015/5187]

Appendix 2. Graphs showing Computed Water-surface Profiles for the 10-, 2-, 1-, and 0.2-Percent Annual-exceedance Probability Flood-peak Discharges and Floodway for Five Selected Stream Reaches in and near Shelby, Ohio

Appendix 3. Precipitation-runoff Model Parameters, Event Data Collected, and Results for the Black Fork Mohican River Basin

\section{Conversion Factors}

\begin{tabular}{lll}
\multicolumn{1}{c}{ Inch/Pound to SI } & & \\
\hline \multicolumn{1}{c}{ Multiply } & By & \multicolumn{1}{c}{ To obtain } \\
\hline inch (in) & \multicolumn{1}{c}{ Length } & \\
foot $(\mathrm{ft})$ & 2.54 & centimeter $(\mathrm{cm})$ \\
mile (mi) & 0.3048 & meter $(\mathrm{m})$ \\
square mile $\left(\mathrm{mi}^{2}\right)$ & 1.609 & kilometer $(\mathrm{km})$ \\
cubic foot per second $\left(\mathrm{ft}^{3} / \mathrm{s}\right)$ & 2.590 & square kilometer $\left(\mathrm{km}^{2}\right)$ \\
\hline
\end{tabular}

Temperature in degrees Celsius $\left({ }^{\circ} \mathrm{C}\right)$ may be converted to degrees Fahrenheit $\left({ }^{\circ} \mathrm{F}\right)$ as follows: ${ }^{\circ} \mathrm{F}=\left(1.8 \times{ }^{\circ} \mathrm{C}\right)+32$

Temperature in degrees Fahrenheit $\left({ }^{\circ} \mathrm{F}\right)$ may be converted to degrees Celsius $\left({ }^{\circ} \mathrm{C}\right)$ as follows: ${ }^{\circ} \mathrm{C}=\left({ }^{\circ} \mathrm{F}-32\right) / 1.8$

Vertical coordinate information is referenced to North American Vertical Datum of 1988 (NAVD 88).

Horizontal coordinate information is referenced to the North American Datum of 1983 (NAD 83). 


\section{Abbreviations}

\begin{tabular}{ll} 
AEP & annual-exceedance probability \\
ALERT & Automated Local Evaluation in Real Time \\
CN & curve number \\
DEM & digital elevation model \\
FEMA & Federal Emergency Management Agency \\
FIRM & Flood Insurance Rate Map \\
FIS & Flood Insurance Study \\
GIS & geographic information system \\
GPS & Global Positioning System \\
HEC & Hydrologic Engineering Center \\
HMS & Hydrologic Modeling System \\
HWM & high-water mark \\
MWCD & Muskingum Watershed Conservancy District \\
NGS & National Geodetic Survey \\
NLCD & National Land Cover Database \\
NRCS & Natural Resources Conservation Service \\
NSSDA & National Standard for Spatial Data Accuracy \\
NWS & National Weather Service \\
OEMA & Ohio Emergency Management Agency \\
OSIP & Ohio Statewide Imagery Program \\
RAS & River Analysis System \\
RMSE & root mean square error \\
RTN & Real-Time Network \\
SCS & Soil Conservation Service \\
SWE & snow water equivalent \\
USACE & U.S. Army Corps of Engineers \\
USGS & U.Seological Survey \\
\hline
\end{tabular}




\section{Acknowledgments}

The authors would like to acknowledge Joe Gies, City Project Coordinator and Ray Lenczowski, City Engineer in Shelby, Ohio, for their cooperation and support throughout this study. The authors thank Brad Brown, Superintendent, city of Shelby Water Treatment Plant for sending the monthly reservoir pumping information. Additionally, the authors thank the Muskingum Watershed Conservancy District for cooperation and support throughout this study. 


\title{
Hydrologic and Hydraulic Analyses for the Black Fork Mohican River Basin in and near Shelby, Ohio
}

\author{
By Carrie A. Huitger, Chad J. Ostheimer, and G.F. Koltun
}

\section{Abstract}

Hydrologic and hydraulic analyses were done for selected reaches of five streams in and near Shelby, Richland County, Ohio. The U.S. Geological Survey (USGS), in cooperation with the Muskingum Watershed Conservancy District, conducted these analyses on the Black Fork Mohican River and four tributaries: Seltzer Park Creek, Seltzer Park Tributary, Tuby Run, and West Branch. Drainage areas of the four stream reaches studied range from 0.51 to 60.3 square miles. The analyses included estimation of the 10-, 2-, 1-, and 0.2-percent annual-exceedance probability (AEP) floodpeak discharges using the USGS Ohio StreamStats application. Peak discharge estimates, along with cross-sectional and hydraulic structure geometries, and estimates of channel roughness coefficients were used as input to step-backwater models. The step-backwater models were used to determine water-surface elevation profiles of four flood-peak discharges and a regulatory floodway. This study involved the installation of, and data collection at, a streamflow-gaging station (Black Fork Mohican River at Shelby, Ohio, 03129197), precipitation gage (Rain gage at Reservoir Number Two at Shelby, Ohio, 405209082393200), and seven submersible pressure transducers on six selected river reaches. Two precipitationrunoff models, one for the winter events and one for nonwinter events for the headwaters of the Black Fork Mohican River, were developed and calibrated using the data collected. With the exception of the runoff curve numbers, all other parameters used in the two precipitation-runoff models were identical. The Nash-Sutcliffe model efficiency coefficients were 0.737 , 0.899 , and 0.544 for the nonwinter events and 0.850 and 0.671 for the winter events. Both of the precipitation-runoff models underestimated the total volume of water, with residual runoff ranging from -0.27 inches to -1.53 inches. The results of this study can be used to assess possible mitigation options and define flood hazard areas that will contribute to the protection of life and property. This study could also assist emergency managers, community officials, and residents in determining when flooding may occur and planning evacuation routes during a flood.

\section{Introduction}

The Black Fork Mohican River and its tributaries have a history of flooding areas of the city of Shelby, Richland County, Ohio (fig. 1) (U.S. Department of Agriculture, 1987), with recent severe flooding occurring in 1987 and 2007. Peak streamflows were estimated to be in excess of the 0.2-percent annual-exceedance probability (AEP) flood-peak discharge for both the 1987 (U.S. Department of Agriculture, 1987) and 2007 floods (Straub and others, 2009). After the 2007 flood, Shelby officials requested the cooperation of the Muskingum Watershed Conservancy District (MWCD) to help investigate and evaluate potential flood-mitigation alternatives. In order to facilitate assessments of alternatives for flood protection, the U.S. Geological Survey (USGS), in cooperation with the MWCD, began a study in 2012 to collect streamflow, precipitation, land elevation, and structure geometry data to better understand the hydrology and hydraulics of the Black Fork Mohican River and four tributaries that will be referred to as: Seltzer Park Creek, Seltzer Park Tributary, Tuby Run, and West Branch (fig. 1).

\section{Purpose and Scope}

This report describes methods and results of hydrologic and hydraulic analyses of the Black Fork Mohican River and four tributaries: Seltzer Park Creek, Seltzer Park Tributary, Tuby Run, and West Branch. The analyses include the estimation of the 10-, 2-, 1-, and 0.2-percent AEP flood-peak discharges, determination of the water-surface elevation profiles for the four flood-peak discharges and for the regulatory floodway, and the development of a precipitation-runoff model of the headwaters of the Black Fork Mohican River basin. 


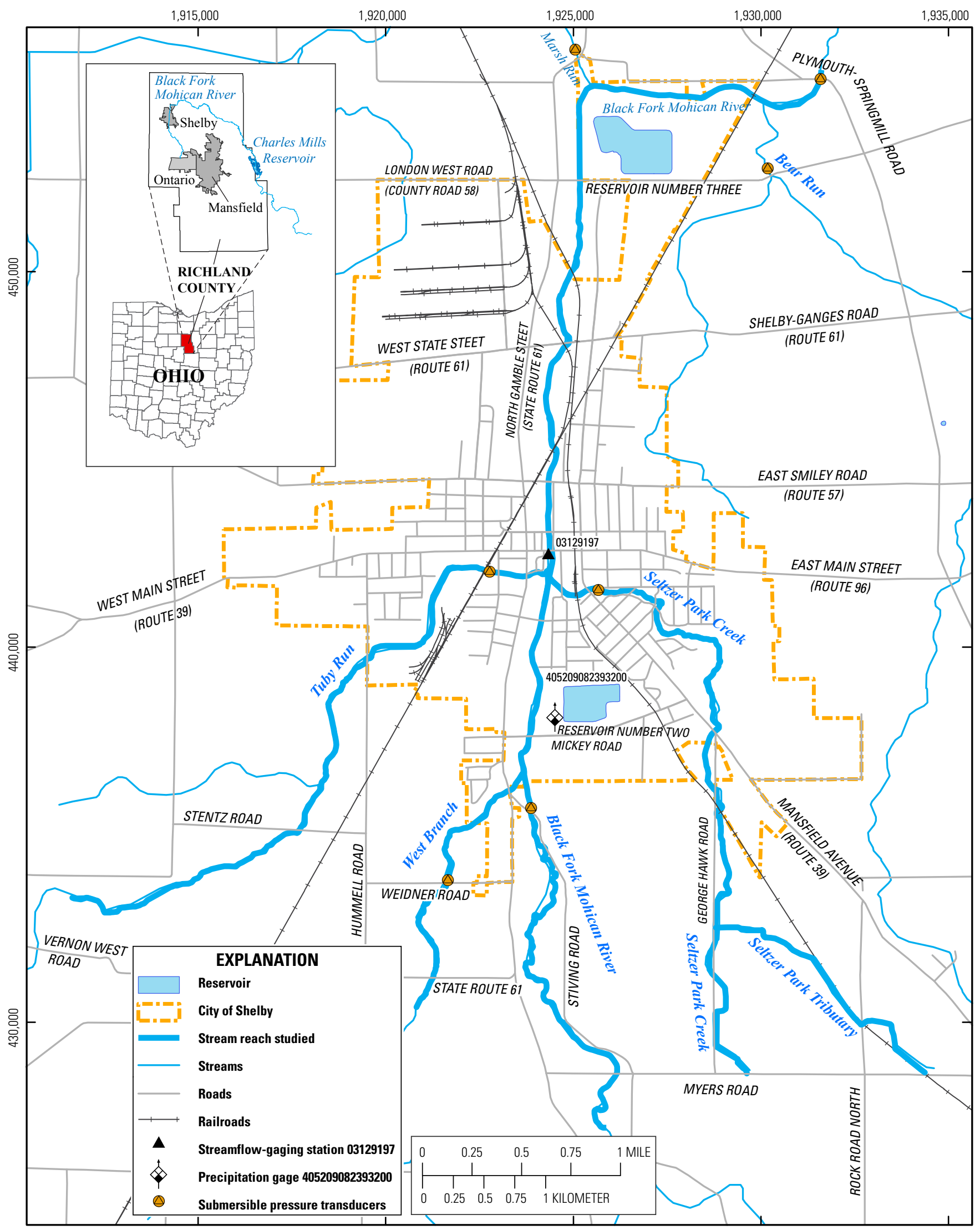

Figure 1. Study area within Richland County in and near Shelby, Ohio. 


\section{Background and Previous Studies}

As a result of numerous floods, the Shelby city council requested a flood-plain management study of the Black Fork Mohican River and its tributaries in 1981. The Natural Resources Conservation Service (NRCS, formerly the Soil Conservation Service [SCS]) conducted the technical phase of the 1980's study, which included: 1) development of flood profiles for the 10-, 2-, 1-, and 0.2-percent AEP floods and 2) creation of inundation maps for the 1- and 0.2-percent AEP floods, and regulatory floodways for the studied streams (U.S. Department of Agriculture, 1987). That flood-plain management study was incorporated into a Federal Emergency Management Agency (FEMA) Flood Insurance Study (FIS) and Flood Insurance Rate Maps (FIRMs) for Shelby in March 1989 (Federal Emergency Management Agency, 1989). In April 2011, the flood-inundation areas were redelineated using new digital base maps for Richland County, which is the current (2015) effective FIS and FIRMs for the county (Federal Emergency Management Agency, 2011). However, no new hydrologic or hydraulic analyses have been done for the Black Fork Mohican River and its tributaries since the 1980's study.

Shelby experienced severe floods in 1987 (U.S.

Department of Agriculture, 1987) and 2007 (Straub and others, 2009). During these events, the downtown area was inundated and there was substantial flood damage to commercial and private structures (U.S. Department of Agriculture, 1987). The USGS estimated the peak discharge for the 2007 flood using indirect determination of discharge methods to assess the magnitude of this event (Straub and others, 2009). For both the 1987 and 2007 floods, the flows were estimated to be in excess of the 0.2-percent AEP flood-peak discharge.

\section{Study Area}

Shelby is located in the northwest quadrant of Richland County in north central Ohio (fig. 1) and has a population of 9,317 (U.S. Census Bureau, 2011). The mean annual precipitation is 36.7 inches (in.) in the basin and approximately 12.7 percent of the area is covered by forest (determined from StreamStats [Koltun and others, 2006]). Land use in the basin headwaters tends to be cultivated crops and developed low-intensity in the lower basin from 2006 National Land Cover Database (NLCD) (Fry and others, 2011). The Black Fork Mohican River, which drains most of northern Richland County, has low to moderate relief with elevations ranging from approximately 1,150 to 1,350 feet (ft) in the study area. For this report, the horizontal datum is the North American Datum of 1983 (NAD 83), Ohio State Plane (Ohio North) coordinates; the vertical datum is the North American Vertical Datum of 1988 (NAVD 88). The headwaters of the Black Fork Mohican River originate about 7 miles (mi) southeast of Shelby near the town of Ontario, Ohio, and the river then flows north where it joins with West Branch near the southern corporate limits of Shelby (fig. 1). The Black Fork Mohican River bisects Shelby, and the tributaries of Tuby Run and Seltzer Park Creek join from the west and east, respectively, just south and upstream of, the downtown area. The drainage area at the Black Fork Mohican River at Shelby, Ohio streamflow-gaging station (03129197) is $28.0 \mathrm{mi}^{2}$ (U.S. Geological Survey, 2015a). The stream continues flowing north from the streamflow-gaging station to the northern corporate limit where it turns east and then southeast, eventually passing through the Charles Mills Reservoir.

\section{Study Approach}

Flood profiles for the 10-, 2-, 1-, and 0.2-percent AEP floods and regulatory floodway were developed using the onedimensional, steady-flow, step-backwater model, version 4.1 of the U.S. Army Corps of Engineers (USACE) Hydrologic Engineering Center's River Analysis System (HEC-RAS), (U.S. Army Corps of Engineers, 2010a, b, c). HEC-RAS models have regional regression estimates as streamflow input for the four selected profiles. These flood profiles and the regulatory floodway have been submitted to FEMA and are being used to update the FIS. Precipitation-runoff models were developed using HEC's Hydrologic Modeling System (HEC-HMS) version 4.0 (U.S. Army Corps of Engineers, 2013), and precipitation data collected throughout the study. In addition to the precipitation data, streamflow and water-level data were collected in the Black Fork Mohican River basin to help calibrate and validate the precipitation-runoff models. Water-level data were collected on two locations on the Black Fork Mohican River and five tributaries; Seltzer Park Creek, Tuby Run, West Branch, Marsh Run, and Bear Run. These models can help community officials and decision makers create potential engineering solutions and evaluate possible flood-mitigation alternatives.

\section{Step-backwater Models}

Channel and overbank roughness coefficients (Manning's n), cross section elevations, and hydraulic-structure geometries were required to develop the step-backwater models.

Estimates for the roughness coefficients ranged in value from 0.025 to 0.048 for the main channels, and from 0.012 to 0.15 for the overbank areas. Cross sections surveyed in the field and synthetic cross sections derived from digital 2-ft contour maps provided by the Richland County Regional Planning Commission were used to establish the 10-, 2-, 1-, 0.2-percent AEP flood profiles for the study reaches. Flood profiles for the Black Fork Mohican River, Seltzer Park Creek, Seltzer Park Tributary, Tuby Run, and West Branch were determined for the reach limits listed in table 1. Estimates of the AEP floodpeak discharges were determined at selected locations along each stream using the USGS Ohio StreamStats application (Koltun and others, 2006) for the five study reaches. Drainage areas of the five stream reaches studied range from 0.51 to 60.3 square miles. 
Table 1. Hydraulic model limits for selected streams in and near Shelby, Ohio.

[Locations shown in figure 1]

\begin{tabular}{lllc}
\hline \multicolumn{1}{c}{ Stream name } & \multicolumn{1}{c}{ Downstream limit } & Upstream limit & $\begin{array}{c}\text { Approximate channel } \\
\text { length (miles) }\end{array}$ \\
\hline $\begin{array}{l}\text { Black Fork } \\
\text { Mohican River }\end{array}$ & Plymouth-Springmill Road & $\begin{array}{c}\text { Approximately 1,750 feet } \\
\text { upstream of Myers Road }\end{array}$ & 7.3 \\
\hline Seltzer Park Creek & $\begin{array}{c}\text { Confluence with Black Fork } \\
\text { Mohican River }\end{array}$ & Myers Road & 3.6 \\
\hline Seltzer Park Tributary & $\begin{array}{c}\text { Confluence with } \\
\text { Seltzer Park Creek }\end{array}$ & Myers Road & 1.4 \\
\hline Tuby Run & $\begin{array}{c}\text { Confluence with Black Fork } \\
\text { Mohican River }\end{array}$ & $\begin{array}{c}\text { Approximately 3,000 feet } \\
\text { downstream of Vernon West Road }\end{array}$ & 3.6 \\
\hline West Branch & $\begin{array}{c}\text { Confluence with Black Fork } \\
\text { Mohican River }\end{array}$ & $\begin{array}{c}\text { Approximately 925 feet } \\
\text { upstream of State Route 61 }\end{array}$ & 1.6 \\
\hline
\end{tabular}

Surveys were made and photographs were taken of hydraulic structures and open-channel cross sections by USGS personnel. A geographic information system (GIS) was used to develop a triangulated irregular network (TIN) from digital 2 - $\mathrm{ft}$ contour data to obtain supplemental cross-sectional data for the reaches studied. In-channel data for all synthetic cross sections were estimated by interpolation between crosssectional data determined from the field surveys. This study surveyed 238 cross sections and 285 synthetic cross sections were developed using the TIN. Geometries of 56 bridges and culverts were also surveyed in the field.

The USGS used both Global Positioning System (GPS) and differential-leveling surveys (hereafter referred to as conventional surveys) for this study. The GPS surveys established a control network at pertinent locations along each of the streams studied. Conventional surveys were done to obtain stream and hydraulic-structure geometry. All conventional survey data collected met third-order accuracy (horizontal and vertical) criteria (Federal Geodetic Control Committee, 1984). GPS surveys were conducted by the USGS using Real-Time Network (RTN) surveying techniques (U.S. Geological Survey, 2014). A control was established using National Geodetic Survey (NGS) benchmarks with published elevations and one benchmark with published horizontal coordinates including elevation. Comparisons of the published and surveyed values for eight bench marks are listed in table 2 . Detailed information about the NGS bench marks can be found at: http://www.ngs.noaa.gov/datasheets/.

\section{Accuracy of the Mapping Data}

Map data accuracy was based on FEMA guidelines and specifications (Federal Emergency Management Agency, 2003). Horizontal accuracy of the map data was assessed using root-mean-square errors (RMSEs) computed for 26 selected, easily identifiable, planimetric features (for example, centerline of road points) distributed across the river basin. The features were obtained from field-survey measurements and measurements selected from $2 \mathrm{ft}$ contourinterval topographic maps overlain with aerial photography. The RMSEs for eastings and northings were 0.78 and $0.67 \mathrm{ft}$, respectively, yielding a radial RMSE $\left(\mathrm{RMSE}_{\mathrm{R}}\right)$ of $1.03 \mathrm{ft}$.

In addition to the elevations listed in table 2, a vertical RMSE $\left(\mathrm{RMSE}_{\mathrm{z}}\right.$ ) was determined from surveyed elevations and digital 2-ft topographic map elevations. Surveyed elevations were compared to the digital map elevations for 178 selected locations and the RMSEz was $0.35 \mathrm{ft}$.

According to the National Standard for Spatial Data Accuracy (NSSDA) (Federal Geographic Data Committee, 1998), the horizontal accuracy requires that the $\mathrm{RMSE}_{\mathrm{R}}$ must be less than $11.0 \mathrm{ft}$ for a map produced at $1 \mathrm{in}$. equal to $500 \mathrm{ft}$. For a 2-ft contour-interval map, the NSSDA vertical accuracy requirements state that the $\mathrm{RMSE}_{\mathrm{z}}$ must be less than $0.6 \mathrm{ft}$. Both the $\operatorname{RMSE}_{\mathrm{R}}(1.03 \mathrm{ft})$ and $\mathrm{RMSE}_{\mathrm{z}}(0.35 \mathrm{ft})$ for this study are lower than the maximum acceptable error, and therefore meet the horizontal and vertical criteria applicable to FEMA Flood Insurance Rate Maps (FIRM) (Federal Emergency Management Agency, 2003). 


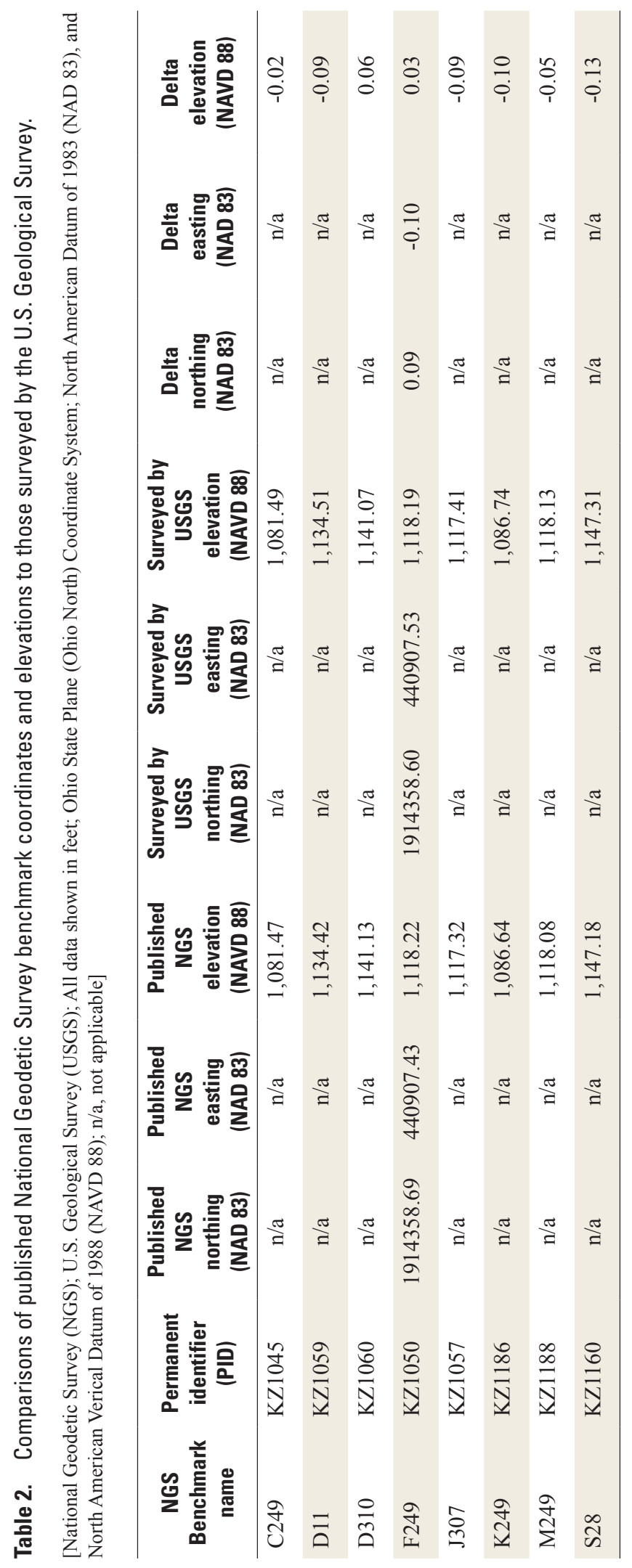


Hydrologic and Hydraulic Analyses for the Black Fork Mohican River Basin in and near Shelby, Ohio

\section{Precipitation-runoff Model}

A precipitation-runoff model of the Black Fork Mohican River basin was developed using precipitation data collected in the basin and streamflow and water-level data collected on selected stream reaches. The HEC-HMS model was prepared for the $60.1 \mathrm{mi}^{2}$ Black Fork Mohican River basin, located in northwest Richland County, just downstream from Shelby (at Plymouth-Springmill Road) (fig. 1). The model was constructed using the HEC Geospatial Hydrologic Modeling Extension (HEC-GeoHMS) version 10.0 (U.S. Army Corps of Engineers, 2010d) for ArcGIS version 10.0 (Environmental Systems Research Institute, 2010). HECGeoHMS uses a digital elevation model (DEM) to delineate watershed boundaries and drainage paths. It then transforms the drainage paths and watershed boundaries into a hydrologic data structure that can be used in HEC-HMS to model the watershed response to precipitation. HEC-GeoHMS creates the HEC-HMS basin model and background map file, and computes physical watershed and stream characteristics. The stream network threshold used for this project is $1.5 \mathrm{mi}^{2}$. A $32.808 \mathrm{ft}$ DEM was used to define the watershed and its characteristics. The DEM was preprocessed following procedures listed in the HEC-GeoHMS User's Manual (U.S. Army Corps of Engineers, 2010d).

The Arc Hydro tool (Environmental Systems Research Institute, 2007) in ArcMap was used to develop a runoffcurve number (CN) (U.S. Department of Agriculture, 2004) grid based on the NRCS Soil Survey Geographic (SSURGO) database (U.S. Department of Agriculture, 2015) and land cover data from the 2006 NLCD (Fry and others, 2011). The 2006 NLCD has fifteen classification categories that, for the purpose of $\mathrm{CN}$ assignment, were aggregated into five supersets of classification: water, low residential development, medium/ high residential development, forest, and agriculture. The $\mathrm{CN}$ grid was used to calculate area weighted composite $\mathrm{CNs}$ for each of 40 subbasins using a combination of land use and soil type characteristics.

Modeling was done with version 4.0 of HEC-HMS (U.S. Army Corps of Engineers, 2013). The HEC-HMS model is capable of simulating infiltration losses, runoff, channel routing, and base flow by means of a variety of methods. The model developed for the Black Fork Mohican River basin uses the SCS CN method to simulate runoff and the MuskingumCunge eight-point method for channel routing (U.S. Army Corps of Engineers, 2013). Base flow was estimated using the recession method with an initial discharge of 0.5 cubic feet per second $\left(\mathrm{ft}^{3} / \mathrm{s}\right)$, a recession constant of 0.3 , and base flow reset threshold type of ratio to peak, using a ratio of 0.15 . Initial abstraction values were intentionally left blank in the model input so that HEC-HMS would automatically calculate the value as 0.2 times the potential maximum retention (which is calculated as a function of the curve number).

Transformation of the excess precipitation to a runoff hydrograph was done by means of the SCS Unit Hydrograph method (U.S. Army Corps of Engineers, 2013) which requires a peak discharge and an estimation of basin lag time. Basin time of concentration and lag times were estimated using the HEC-GeoHMS extension in ArcGIS (Environmental Systems Research Institute, 2010). The CN lag method was used to estimate the lag time for all 40 subbasins.

The HEC-HMS model constructed for the Black Fork Mohican River basin contains 21 reaches and 40 subbasins ranging in area from 0.001 to $4.062 \mathrm{mi}^{2}$. Muskingum-Cunge routing parameters such as reach length and energy slope were estimated from the DEM and DEM-derived drainage paths. The 8-point representation of the channel cross section was used in the model with 15 different cross sections. Crosssection geometries for reaches along the Black Fork Mohican River, Tuby Run, Seltzer Park Creek, Seltzer Park Tributary, and West Branch reach were based on surveyed data. Crosssection geometries for other reaches and tributaries in the model were estimated on the basis of aerial photography and digital 2-ft contour data supplied from the Richland County Regional Planning Commission. Roughness coefficients for the channels and overbank areas were estimated from a limited number of field-based observations and from aerial photography. The aerial photography was obtained from the Ohio Geographically Referenced Information Program (2006) within the Ohio Office of Information Technology. Roughness coefficients used in the model for the channels ranged from 0.034 to 0.044 , and the overbank areas ranged from 0.028 to 0.078 .

There are two diversion elements in the HEC-HMS model: Diversion 1 is part of the municipal water supply for Shelby, for which water is pumped from the Black Fork Mohican River into Reservoir Number Two, near the precipitation gage (fig. 1); Diversion 2 is located on Marsh Run, pumping from Marsh Run into Reservoir Number Three, near the lower end of the basin. The monthly pumping information for both reservoirs was obtained from the city of Shelby Water Treatment Plant (Brad Brown, written communication). Reservoir Number Three pumped $56 \mathrm{ft}^{3} / \mathrm{s}$ during the event modeled in June 2013, no water was pumped during the other runoff events modeled. Reservoir Number Two pumped from 12 to $106 \mathrm{ft}^{3} / \mathrm{s}$, during the runoff events modeled in April, June, and July 2013; each event was modeled beginning approximately 30 days prior to the peak event.

\section{Streamflow and Precipitation}

Streamflow and precipitation data were collected in the basin beginning in June and July 2012, respectively, and are still (2015) being collected. Streamflow data were used to calibrate and validate the HEC-HMS model and precipitation data were used as input to the model. The USGS installed streamflow-gaging station number 03129197 on the Black Fork Mohican River (U.S. Geological Survey, 2015a) in June 2012, located in downtown Shelby, on the left upstream bank near the Main Street Bridge (fig. 1). The stream gage consists of an orifice line anchored in the stream, connected to a bank-mounted nonsubmersible pressure transducer, and a data 
logger set to record water-level data at 15 -minute intervals. A gage datum of 1,065.30 ft (NAVD 88) was determined for the streamflow-gaging station by differential survey. The stream gage was equipped with a Geostationary Operational Environmental Satellite (GOES) transmitter, which the USGS uses to transmit data on an hourly basis, and Automated Local Evaluation in Real Time ${ }^{1}$ (ALERT) telemetry. A voice modem was installed to call a preprogrammed local emergency phone number when the stream stage either reaches a designated action height or exceeds a specified rate of increase. Near real-time data from the stream gage telemetered through the GOES transmitter is used by the USGS to monitor equipment performance and provide back-up data in case the ALERTbased data stream is interrupted. A detailed description of the methods used for data collection by the USGS, including discharge measurements and crest-stage gages, can be found in Rantz and others (1982).

Precipitation data were collected beginning in July 2012, when the USGS installed a heated precipitation gage (station number 405209082393200) (U.S. Geological Survey, 2015b) with ALERT telemetry near Reservoir Number Two (fig. 1). The precipitation data obtained from the gage was used as input to the precipitation-runoff models. The precipitation data are quality controlled with two annual inspections and calibrations. These data are stored in the National Water Information System (NWIS) and are available upon request from the USGS. There also is an Ohio Emergency Management Agency (OEMA) precipitation gage near the city of Ontario approximately 8.5 miles south of Shelby (fig. 1) that was used for determining precipitation distribution, but it is located outside the Black Fork Mohican River basin. Precipitation and temperature information also were obtained from the Mansfield LAHM regional airport station number 14891/MFD (National Oceanic and Atmospheric Administration, 2015a) located approximately 8 miles southeast of Shelby (fig. 1) in an adjacent drainage basin.

\section{Water Levels}

The USGS deployed seven submersible pressure transducers to record stream water levels on the following seven locations: 1) Black Fork Mohican River upstream from the confluence of West Branch, 2) West Branch, 3) Seltzer Park Creek, 4) Tuby Run, 5) Marsh Run, 6) Bear Run, and 7) Black Fork Mohican River at Plymouth-Springmill Road (fig. 1). Data collection from the sensors began in July 2012 and continued through August 2014. The sensors deployed on the tributaries to the Black Fork Mohican River were installed upstream from the expected influence of backwater ${ }^{2}$. The

\footnotetext{
${ }^{1}$ The ALERT system is a radio network operated by the Ohio Emergency Management Agency (OEMA) also referred to as the State of Ohio Rain/Snow Monitoring System (STORMS) program.

${ }^{2}$ Water backed up or retarded in its course as compared with its normal or natural condition of flow.
}

sensors collect time series water-level (stream stage ${ }^{3}$ ) data at seven locations throughout the Black Fork Mohican River basin. The USGS obtained NAVD 88 elevations for the water level data using differential survey methods. Water-level data were corrected to account for changing barometric pressure measured using a barometric pressure sensor located at streamflow-gaging station 03129197. The water-level data were needed to characterize the hydrologic response of the stream network affecting Shelby and were used to aid in the timing of the runoff for hydrologic models of the headwaters of the Black Fork Mohican River basin.

\section{Step-backwater Analyses}

This study included updating the one dimensional, steady-state hydraulic model using HEC-RAS 4.1 (U.S. Army Corps of Engineers, 2010a, b, and c) for the stream reaches listed in table 1. Flood profiles for the 10-, 2-, 1-, and 0.2-percent AEP floods and regulatory floodway were developed using HEC-RAS, were submitted to FEMA, and are being used to update the FIS. The USGS obtained the digital 2-ft contour mapping data from the Richland County Regional Planning Commission and used the data as the base map for the models.

\section{Estimation of Peak Flows}

Because the stream gage on the Black Fork Mohican River was established in 2012, there was not sufficient historical streamflow data (generally 10 years) to calculate the flood-peak discharges using observed streamflow data. Therefore, regional regression equations were used to estimate the 10-, 2-, 1- and 0.2-percent AEP flood-peak discharges using the Ohio StreamStats application (Koltun and others, 2006). The StreamStats application solves regional regression equations that use: 1) drainage area, 2) main channel slope (determined by the 10-85 method, SL10-85), and 3) storage (percentage of drainage classified as water and wetlands area) as explanatory variables. The explanatory variables are computed within StreamStats on the basis of geospatial datasets. StreamStats estimates are based on the assumption that the basin is not appreciably regulated and is without significant urbanization (Koltun and others, 2006). The resulting floodpeak discharge estimates are listed in table 3.

\footnotetext{
${ }^{3}$ Stage refers to a stream's height above a reference point. Stage, together with a reference datum, can be used to determine water-surface elevation.
} 
Table 3. Summary of the explanatory variable values used in the regression equations and the final 10-, 2-, 1-, and 0.2-percent annual-exceedance probability flood-peak discharge estimates and locations for the selected streams in and near Shelby, Ohio.

$[\%$, percent $]$

\begin{tabular}{|c|c|c|c|c|c|c|c|c|c|}
\hline \multirow[t]{2}{*}{ Location Description } & \multirow[t]{2}{*}{ Latitude } & \multirow[t]{2}{*}{ Longitude } & \multirow[t]{2}{*}{$\begin{array}{l}\text { Drainage } \\
\text { area, } \\
\text { square } \\
\text { miles }\end{array}$} & \multirow{2}{*}{$\begin{array}{l}\text { Main } \\
\text { channel } \\
\text { slope', } \\
\text { feet per } \\
\text { mile }\end{array}$} & \multirow{2}{*}{$\begin{array}{l}\text { Storage } \\
\text { (water or } \\
\text { wetlands } \\
\text { area), } \\
\text { percentage }\end{array}$} & \multicolumn{4}{|c|}{$\begin{array}{c}\text { Annual-exceedance probability } \\
\text { flood-peak discharges }{ }^{2} \\
\text { cubic feet per second }\end{array}$} \\
\hline & & & & & & $10 \%$ & $2 \%$ & $1 \%$ & $0.2 \%$ \\
\hline \multicolumn{10}{|c|}{ Black Fork Mohican River } \\
\hline $\begin{array}{l}\text { At Plymouth-Springmill } \\
\text { Road }\end{array}$ & $40^{\circ} 54^{\prime} 57^{\prime \prime}$ & $82^{\circ} 38^{\prime} 02^{\prime \prime}$ & 60.3 & 18.9 & 1.41 & 4,350 & 6,390 & 7,290 & 9,360 \\
\hline Above Bear Run & $40^{\circ} 54^{\prime} 51^{\prime \prime}$ & $82^{\circ} 38^{\prime} 21^{\prime \prime}$ & 52.4 & 19.8 & 1.37 & 3,960 & 5,830 & 6,660 & 8,560 \\
\hline Above Marsh Run & $40^{\circ} 54^{\prime} 55^{\prime \prime}$ & $82^{\circ} 39^{\prime} 21^{\prime \prime}$ & 31.3 & 21.9 & 1.38 & 2,720 & 4,030 & 4,610 & 5,940 \\
\hline Above Seltzer Park Creek & $40^{\circ} 52^{\prime} 46^{\prime \prime}$ & $82^{\circ} 39^{\prime} 36^{\prime \prime}$ & 20.9 & 28.3 & 1.39 & 2,100 & 3,140 & 3,600 & 4,660 \\
\hline Above West Branch & $40^{\circ} 51^{\prime} 52^{\prime \prime}$ & $82^{\circ} 39^{\prime} 43^{\prime \prime}$ & 15.5 & 32.5 & 1.10 & 1,780 & 2,680 & 3,080 & 4,010 \\
\hline \multicolumn{10}{|c|}{ Seltzer Park Creek } \\
\hline At mouth & $40^{\circ} 52^{\prime} 46^{\prime \prime}$ & $82^{\circ} 39^{\prime} 35^{\prime \prime}$ & 3.25 & 18.1 & 2.50 & 425 & 623 & 709 & 905 \\
\hline Above unnamed tributary & $40^{\circ} 52^{\prime} 27^{\prime \prime}$ & $82^{\circ} 38^{\prime} 35^{\prime \prime}$ & 2.24 & 16.4 & 2.69 & 310 & 453 & 515 & 655 \\
\hline $\begin{array}{l}\text { Above Seltzer Park } \\
\text { Tributary }\end{array}$ & $40^{\circ} 51^{\prime} 13^{\prime \prime}$ & $82^{\circ} 38^{\prime} 35^{\prime \prime}$ & 0.94 & 17.1 & 4.05 & 146 & 212 & 239 & 303 \\
\hline \multicolumn{10}{|c|}{ Seltzer Park Tributary } \\
\hline At mouth & $40^{\circ} 51^{\prime} 14^{\prime \prime}$ & $82^{\circ} 38^{\prime} 35^{\prime \prime}$ & 0.51 & 23.7 & 2.08 & 113 & 169 & 193 & 249 \\
\hline \multicolumn{10}{|c|}{ Tuby Run } \\
\hline At mouth & $40^{\circ} 52^{\prime} 47^{\prime \prime}$ & $82^{\circ} 39^{\prime} 36^{\prime \prime}$ & 3.79 & 9.2 & 0.96 & 486 & 711 & 808 & 1,030 \\
\hline \multicolumn{10}{|c|}{ West Branch } \\
\hline At mouth & $40^{\circ} 51^{\prime} 52^{\prime \prime}$ & $82^{\circ} 39^{\prime} 45^{\prime \prime}$ & 4.76 & 20.8 & 0.95 & 676 & 1,010 & 1,160 & 1,500 \\
\hline
\end{tabular}

${ }^{1}$ The main channel slope is determined by the new channel slope characteristic (SL10-85) (Koltun and others, 2006).

${ }^{2}$ Determined using StreamStats Web Application for Ohio, solves regional regression equations (Koltun and others, 2006).

\section{Determination of Starting Water-surface Elevations}

The downstream boundary condition for each of the study reaches was normal depth, determined from a slopeconveyance calculation (Manning's equation). The energy slope was assumed to be equal to the average streambed slope as determined from field surveys (table 4). In HEC-RAS, the conveyance computations option was set to breaks in $n$ values only, and was used to model flood profiles for all streams analyzed in this study. Unless otherwise mentioned, default settings for HEC-RAS were used; the default setting for the friction slope method for steady flow is average conveyance (U.S. Army Corps of Engineers, 2010a, b, c).

\section{Model Calibration}

At the time the Black Fork Mohican River hydraulic model was built, the stage-discharge rating for the Black Fork Mohican River at Shelby, Ohio (streamflow-gaging station 03129197), was still being developed. A total of 17 discharge measurements had been made with a maximum measured discharge of $760 \mathrm{ft}^{3} / \mathrm{s}$ - a value much smaller than the estimated 10-percent AEP flood-peak discharge of $2,720 \mathrm{ft}^{3} / \mathrm{s}$. The rating curve was developed using both measured discharges and hydraulic model output (for the upper end of the rating). As a result, the rating could not be used for model calibration at higher flows because that portion of the rating was derived from model results. 


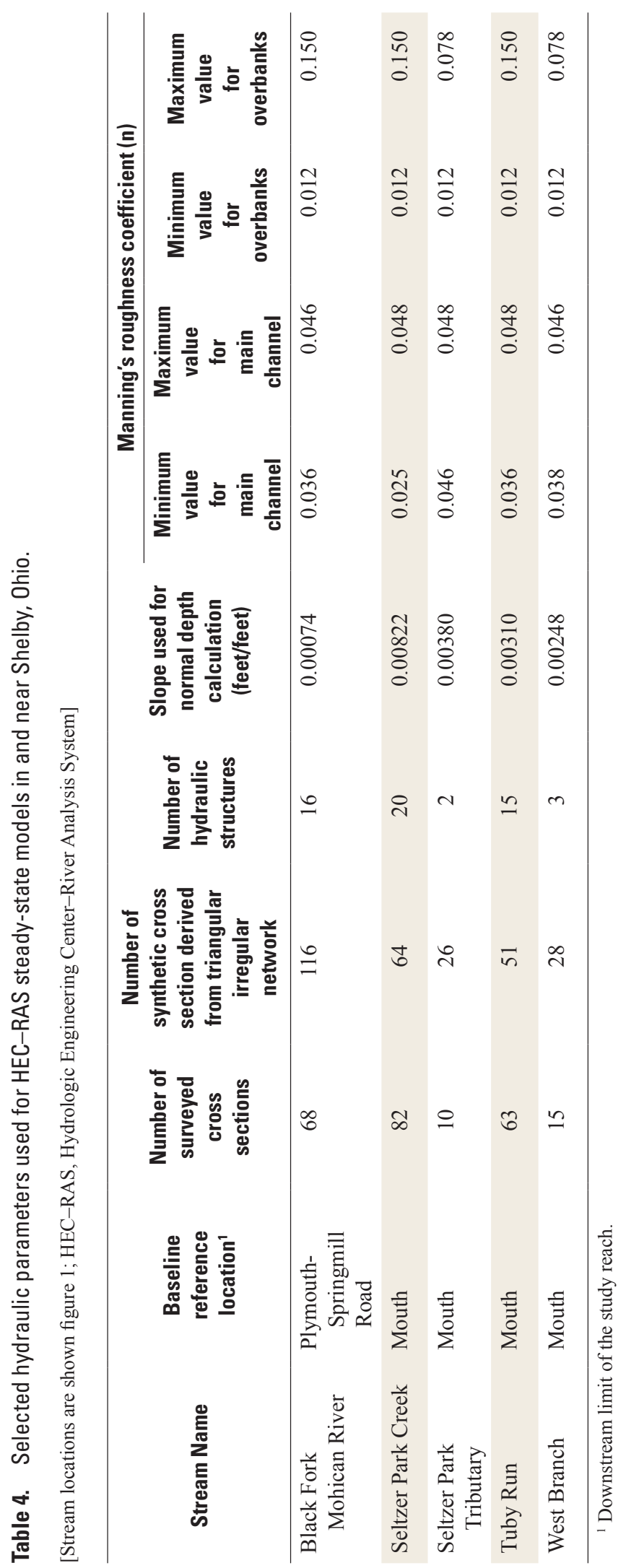


After the 2007 flood event on the Black Fork Mohican River in Shelby, the USGS flagged and surveyed high-water marks (HWMs) and developed a flood profile (Straub and others, 2009). In addition, the peak discharge was computed using the indirect method for contracted-openings (Rantz and others, 1982) for the railroad bridge at hydraulic model river station 12,084 ft (located above Marsh Run). The 2007 flood-peak discharge $\left(6,340 \mathrm{ft}^{3} / \mathrm{s}\right)$ exceeded the estimated 0.2-percent AEP flood-peak discharge of $5,940 \mathrm{ft}^{3} / \mathrm{s}$ (table 3). Between the 2007 flood event and the start of this project in 2012, a second railroad bridge (near hydraulic model river station $14,275 \mathrm{ft}$ ) was determined to cause a notable amount of backwater (Federal Emergency Management Agency, 2011) and was removed. Therefore, HWMs obtained upstream from the second railroad bridge could not be used to calibrate the hydraulic model for this study.

One HWM, at the contracted-opening railroad bridge (hydraulic river station 12,084 ft), was available for model calibration because the other HWMs along the reach may have been influenced by the removal of the second railroad bridge. For the calibration, Manning's roughness coefficients were adjusted from the original field estimates until the results of the hydraulic computations closely agreed (within $0.06 \mathrm{ft}$ ) with the 2007 HWM. Final Manning's roughness coefficients for the Black Fork Mohican River ranged in value from 0.036 to 0.046 for the main channel and from 0.012 to 0.150 for the overbanks (table 4). No stream gage or HWM data were available for calibration of the Seltzer Park Creek, Seltzer Park Tributary, Tuby Run, or West Branch hydraulic models.

Tables and profile plots of the water-surface elevations for the 10-, 2-, 1-, and 0.2-percent AEP flood-peak discharges and the floodway from model output for each of the five study stream reaches can be found in appendixes 1 and 2 (tables 1-1 through $1-5$ and figs. 2-1 through 2-5).

\section{Precipitation-runoff Model Analyses}

Precipitation-runoff models were developed using precipitation data and calibrated to the streamflow data collected from July 2012 through August 2014. From the start of data collection, there have been numerous runoff events within the basin. The five events with the highest peak streamflows at the Black Fork Mohican River at Shelby, Ohio (streamflow-gaging station 03129197) were used to calibrate the HEC-HMS model. The peak streamflow events were: $1,250 \mathrm{ft}^{3} / \mathrm{s}$ on April 12, 2013 (model run 8); 1,440 ft ${ }^{3} / \mathrm{s}$ on June 13, 2013 (model run 9); 4,130 ft3/s on July 9, 2013 (model run 10); 1,750 ft3/s on December 22, 2013 (model run 11), and; $2,040 \mathrm{ft}^{3} / \mathrm{s}$ on February 21, 2014 (model run 12) (table 5). The model included 12 runs, but focused primarily on the five highest events and the precipitation data collected at the Shelby precipitation gage. Initially, rainfall was modeled based on frequency-based hypothetical storms and other precipitation data from nearby precipitation gages. Once enough data were collected at the Shelby precipitation gage, the focus was on the five highest events.
The information described in the following sections summarizes the precipitation-runoff model analyses. Details about the development of the models and event model runs can be found in Appendix 3.

The initial estimates of loss and the transform parameters in the models were adjusted to better reproduce the observed peak streamflow during peak streamflow events. Compared to initial estimates, CNs were lowered and lag times were increased in order to improve the fit of the model results with the observed data.

Upon examination of results from the initial modeling runs, it appeared that runoff characteristics were different for winter and nonwinter events. Previous research (Price, 1998; Van Mullem and others, 2002) indicated that CNs may be higher in the winter when there is less ground cover and it is more likely to be wet or snow covered; lower CNs are expected in nonwinter periods when the ground is drier and there is more vegetation. Consequently, two models were developed, one for winter periods (December through February) and one for nonwinter periods (March through November). The month ranges shown are a general approximation for the runoff events modeled and any model with snow or snowmelt during the runoff event modeled would be considered a winter period. All parameters are the same in both models except for the CNs. The CNs in the nonwinter model (used for runs 8,9 , and 10) were 20 percent lower than the CNs in the winter model (used for runs 11 and 12) to better approximate the seasonal differences in the observed peak discharges.

\section{Limitations of the Model}

The lack of information on snow water equivalent (SWE), snow depth, and snowmelt within the basin resulted in added uncertainty for events during the winter period. Additionally, there was only one precipitation gage at Reservoir Number Two at Shelby (405209082393200) within the $60.1 \mathrm{mi}^{2}$ basin. The use of that point measurement to determine the duration and intensity of precipitation throughout the entire basin is less than ideal-especially during spring and summer convective storms when rainfall characteristics can be highly variable spatially. The National Weather Service (NWS) recommends a minimum density of precipitation gages per area for a flood warning network, which would be more than three gages for this study area (U.S. Army Corps of Engineers, 2000).

The data collection period for model development was 2 years in length, and four of the five runoff events during this time were less than the 10-percent AEP flood peak discharge. The highest runoff event (July 9, 2013) was approximately a 2-percent AEP peak discharge. Calibrating and verifying the models with smaller runoff events leads to uncertainty in simulating the larger runoff events (greater than a 2-percent AEP flood); therefore, if the model is used to simulate larger events, it will need to be calibrated to a similarly sized storm event (U.S. Army Corps of Engineers, 2000). 
Table 5. Summary data from the Black Fork Mohican River at Shelby, Ohio streamflow-gaging station 03129197, including the observed data from selected dates, estimates obtained using the HEC-HMS precipitation-runoff model, and the model performance statistics.

[HEC-HMS, Hydrologic Engineering Center-Hydrologic Modeling System; EDT, Eastern Daylight Time; All times reported in EDT, 24-hour time.]

\begin{tabular}{|c|c|c|c|c|c|}
\hline \multirow{2}{*}{$\begin{array}{c}\text { Location description } \\
\text { Black Fork Mohican River } \\
\text { and model } \\
\text { output statistic }\end{array}$} & \multicolumn{5}{|c|}{ Peak streamflow for five events modeled and observed data (cubic feet per second) } \\
\hline & $\begin{array}{c}\text { Run } 8 \\
4 / 12 / 2013\end{array}$ & $\begin{array}{c}\text { Run } 9 \\
6 / 13 / 2013\end{array}$ & $\begin{array}{c}\text { Run } 10 \\
7 / 9 / 2013\end{array}$ & $\begin{array}{c}\text { Run } 11 \\
12 / 22 / 2013\end{array}$ & $\begin{array}{c}\text { Run } 12 \\
2 / 21 / 2014\end{array}$ \\
\hline $\begin{array}{l}\text { Observed data from } \\
\text { streamgage } 03129197\end{array}$ & $\begin{array}{r}1,250 \text { at } \\
03: 00\end{array}$ & $\begin{array}{r}1,440 \text { at } \\
07: 15\end{array}$ & $\begin{array}{l}\text { 4,130 at approximately } \\
09: 00^{1}\end{array}$ & $\begin{array}{r}1,750 \text { at } \\
06: 15\end{array}$ & $\begin{array}{r}2,040 \text { at } \\
06: 45\end{array}$ \\
\hline $\begin{array}{l}\text { Simulated data from HEC- } \\
\text { HMS at the streamgage } \\
\text { location, hydrologic } \\
\text { element "UserPoint2" }\end{array}$ & $\begin{array}{r}1,970 \text { at } \\
02: 20\end{array}$ & $\begin{array}{r}1,670 \text { at } \\
05: 55\end{array}$ & $\begin{array}{l}3,590 \text { on } 7 / 8 \text { at } 23: 20 \\
3,470 \text { on } 7 / 9 \text { at } 06: 50^{2} \\
3,620 \text { on } 7 / 10 \text { at } 19: 25\end{array}$ & $\begin{array}{r}1,740 \text { at } \\
05: 36\end{array}$ & $\begin{array}{r}1,900 \text { at } \\
06: 50\end{array}$ \\
\hline
\end{tabular}

Precipitation runoff models computed results and output statistics at the stream gage location

\begin{tabular}{|c|c|c|c|c|c|}
\hline $\begin{array}{l}\text { Percentage error of the } \\
\text { simulated data relative } \\
\text { to the observed data }\end{array}$ & $-58 \%$ & $-16 \%$ & $16 \%$ & $0.6 \%$ & $6.9 \%$ \\
\hline $\begin{array}{l}\text { Nash-Sutcliffe model } \\
\text { efficiency coefficient }{ }^{3}\end{array}$ & 0.737 & 0.899 & 0.544 & 0.850 & 0.671 \\
\hline $\begin{array}{l}\text { Observed runoff volume } \\
\text { (inches) }\end{array}$ & 3.14 & 1.83 & 7.26 & 2.93 & 2.51 \\
\hline $\begin{array}{l}\text { Simulated runoff volume } \\
\text { (inches) }\end{array}$ & 1.61 & 1.56 & 6.57 & 1.71 & 0.99 \\
\hline $\begin{array}{l}\text { Residual runoff volume } \\
\text { (inches) }\end{array}$ & -1.53 & -0.27 & -0.69 & -1.22 & -1.52 \\
\hline
\end{tabular}

\footnotetext{
${ }^{1}$ Estimated due to gage malfunction, peak stage elevation obtained from crest stage gage, verified with high water mark surveys, and used the rating curve to estimate the peak streamflow.

${ }^{2}$ The model estimates results with three similar peak streamflows, all within approximately $4 \%$, because the gage malfunctioned, time of peak is unknown, it is estimated at 09:00 AM 7/9/14; therefore the three simulated peakflow data are listed in the table and used the simulated peak of 3,470 $\mathrm{ft}^{3} / \mathrm{s}$ from $7 / 9 / 14$ to compute the absolute percent error relative to the observed data.

${ }^{3}$ Is a goodness of fit statistic that is used to assess the predictive power of models, closer to one is a better match of simulated discharge to observed (Nash and Sutcliffe, 1970).
} 


\section{Results and Summary of the Model}

Observed and simulated peak flows and the error of the simulated peak flow as a percentage of the observed peak flows for the Black Fork Mohican River at the streamflowgaging station (03129197) are shown in table 5. The Nash-Sutcliffe model efficiency coefficient is a goodness of fit statistic that is used to assess the predictive power of hydrologic models (Nash and Sutcliffe, 1970); efficiencies can range from $-\infty$ to 1 , and closer to 1 is a better match of simulated discharge to the observed discharge. The nonwinter event simulations (model runs 8, 9, and 10) have Nash-Sutcliffe model efficiency coefficients of $0.737,0.899$, and 0.544 , respectively. During the runoff event on July 9, 2013 (model run 10), there was an electrical issue at the stream gage - a suspected lighting strike - causing the gage to malfunction. Therefore, the timing of the peak was estimated and the peak water-surface elevation was obtained from the crest-stage gage. This peak water-surface elevation was verified with HWM surveys following methods described by Rantz and others (1982).

The nonwinter-event simulations-model runs 8,9 , and 10 - simulated the timing of the initial rise in the hydrograph reasonably well, but they generally overestimated the peak flows and receded faster than what was observed, resulting in an underestimate of the total volume of water passing the stream gage location. The residual runoff volumes in inches for the nonwinter simulations were -1.53 in., -0.27 in., and -0.69 in., respectively (table 5).

The winter-event simulations (model runs 11 and 12) also simulated the timing and magnitude of the peaks reasonably well, but the timing of the initial rise of the hydrograph differed and the overall volumes of water were underestimated. The residual runoff volumes for the winter simulations were -1.22 in. and -1.52 in. for model runs 11 and 12. Inaccuracies in the winter events likely are due in part to uncertainty regarding the amount of snowpack on the ground, density of the snowpack, the melt rates of the snow, soil moisture content, and depth of frozen soil. The winter event simulations had Nash-Sutcliffe model efficiency coefficients of 0.850 and 0.671 .

Additional information regarding the HEC-HMS model parameters, event data collected, and results can be found in appendix 3 (figs. 3-1 through 3-11 and tables 3-1 through 3-5).

\section{Summary}

This study was done by the U.S. Geological Survey (USGS) in cooperation with the Muskingum Watershed Conservancy District and will be used to assist officials in assessing various alternatives to mitigate flood hazards in and near the city of Shelby, in Richland County, Ohio, that will contribute to the protection of life and property. The Black Fork Mohican River and its tributaries have a history of flooding around Shelby with recent major flooding in 1987 and 2007. Hydrologic and hydraulic analyses were done for selected reaches of five streams: Black Fork Mohican River, Seltzer Park Creek, Seltzer Park Tributary, Tuby Run, and West Branch. Drainage areas of the five stream reaches studied range from 0.51 to 60.3 square miles. The 10-, 2-, 1-, and 0.2 -percent annual-exceedance probability (AEP) flood-peak discharges for the streams were estimated using the USGS Ohio StreamStats application. Water-surface elevation profiles for four flood-peak discharges and for a regulatory floodway were determined using the step-backwater Hydrologic Engineering Center-River Analysis System model. Cross-section elevation data, structure geometries, and roughness coefficients were collected or assessed in the field and used as input for the models. Flood profiles for the 10-, 2-, 1-, and 0.2-percent AEP floods and regulatory floodway were developed using HEC-RAS, were submitted to FEMA, and are being used to update the FIS.

This study included the installation of a streamflowgaging station on the Black Fork Mohican River at Shelby (03129197) just upstream of Main Street, and for a precipitation gage near Reservoir Number Two at Shelby (405209082393200) beginning in June and July 2012. Data collected from seven stream submersible pressure transducers (in operation from July 2012 through August 2014) were used to aid in the timing of runoff for the hydrologic models of the headwaters of the Black Fork Mohican River basin. Two Hydrologic Engineering Center-Hydrologic Modeling System precipitation-runoff models were developed with different curve numbers $(\mathrm{CNs})$ : one for winter periods (December through February) and one for nonwinter periods (March through November); all other parameters were the same. The CNs in the nonwinter model (used for runs 8, 9, and 10) were 20 percent lower than the CNs in the winter model (used for runs 11 and 12) to better approximate the seasonal differences in the observed peak discharges. The Nash-Sutcliffe model efficiency coefficients were $0.737,0.899$, and 0.544 for the nonwinter events (model runs 8,9 , and 10); for the winter events the efficiency coefficients were 0.850 and 0.671 (model runs 11 and 12). Both of the precipitation-runoff models underestimate the total runoff volume of water, with residual runoff ranging from -0.27 in to -1.53 inches. 


\section{References Cited}

Environmental Systems Research Institute, Inc., 2007, Hydro data model: Environmental Systems Research Institute, Inc., accessed September 4, 2015, at http://resources.arcgis.com/ en/communities/hydro/01vn00000010000000.htm.

Environmental Systems Research Institute, Inc., 2010, ArcGIS, accessed on August 31, 2015, at http://www.esri.com/ software/arcgis/.

Federal Emergency Management Agency, 1989, Flood insurance study, city of Shelby, Ohio, Richland County, March 2, 1989 [variously paged].

Federal Emergency Management Agency, 2002, Guidelines and specifications for flood hazard mapping partners, Appendix C: Guidance for riverine flooding analyses and mapping, February 2002, 51 p., accessed on August 31, 2015, at URL http://www.fema.gov/media-library/assets/ documents/13948.

Federal Emergency Management Agency, 2003, Guidelines and specifications for flood hazard mapping partners, Appendix K: Format and standards for flood insurance rate maps, April 2003, 102 p., accessed on August 31, 2015, at http://www.fema.gov/media-library/assets/documents/13948.

Federal Emergency Management Agency, 2011, Flood insurance study number 39139CV000A, Richland County, Ohio and incorporated areas: April 4, 2011, [variously paged].

Federal Geodetic Control Committee, 1984, Standards and specifications for geodetic control networks: 34 p.

Federal Geographic Data Committee, 1998a, Geospatial positioning accuracy standards, part 2: Standards for Geodetic Networks, FGDC-STD-007.2-1998, 6 p., accessed on October 6, 2015, at https://www.fgdc.gov/standards/projects/FGDC-standards-projects/accuracy/part2/chapter2.

Federal Geographic Data Committee, 1998b, Geospatial positioning accuracy standards, part 3: National standard for spatial data accuracy FGDC-STD-007.3-1998, 25 p., accessed on October 6, 2015, at https://www.fgdc.gov/standards/projects/FGDC-standards-projects/accuracy/part3/ chapter3.

Fry, J., Xian, G., Jin, S., Dewitz, J., Homer, C., Yang, L., Barnes, C., Herold, N., and Wickham, J., 2011, Completion of the 2006 national land cover database for the conterminous United States: PE\&RS, v. 77, no. 9, p. 858-864, accessed on June 29, 2015, at http://www.mrlc.gov/ nlcd2006.php.
Kirk, S.C., compiler, 2013a, Monthly water inventory report for Ohio, June 2013: Ohio Department of Natural Resources Division of Water, $4 \mathrm{p}$.

Kirk, S.C., compiler, 2013b, Monthly water inventory report for Ohio, July 2013: Ohio Department of Natural Resources Division of Water, $4 \mathrm{p}$.

Koltun, G.F., Kula, S.P., and Puskas, B.M., 2006, A Streamflow statistics (StreamStats) web application for Ohio: U.S. Geological Survey Scientific Investigations Report 20065312, 62 p., accessed September 1, 2015, at http://pubs. usgs.gov/sir/2006/5312/.

Nash, J.E. and Sutcliffe, J.V., 1970, River flow forecasting through conceptual models part I-A discussion of principles: Journal of Hydrology, v. 10, no. 3, p. 282-290.

National Oceanic and Atmospheric Administration, 2006, NOAA atlas 14 point precipitation frequency estimates: $\mathrm{OH}$ : National Weather Service, Hydrometeorological Design Studies Center Web page, accessed April 1, 2013, at http://hdsc.nws.noaa.gov/hdsc/pfds/pfds_map_cont. html?bkmrk $=$ oh.

National Oceanic and Atmospheric Administration, 2014a, Interactive snow information, MFD - LAHM municipal airport: National Operational Hydrologic Remote Sensing Center Web page, accessed on November 10, 2014, at http:// www.nohrsc.noaa.gov/interactive/html/graph.html?station= $\mathrm{MFD} \& \mathrm{w}=600 \& \mathrm{~h}=400 \& \mathrm{o}=\mathrm{a} \& \mathrm{uc}=0 \& \mathrm{by}=2013 \& \mathrm{bm}=1 \& \mathrm{bd}=$ $3 \& \mathrm{bh}=6 \&$ ey $=2013 \& \mathrm{em}=1 \& \mathrm{ed}=23 \& \mathrm{eh}=6 \&$ data $=0 \&$ units $=0$ \&region $=$ us.

National Oceanic and Atmospheric Administration, 2014b, Interactive snow information, OH-SN-3 - Tiffin 5.2 SE, Tiffin, Ohio: National Operational Hydrologic Remote Sensing Center Web page, accessed on November 10, 2014, at http://www.nohrsc.noaa.gov/interactive/html/graph. $\mathrm{html}$ ? station $=\mathrm{OH}-\mathrm{SN}-3 \& \mathrm{w}=600 \& \mathrm{~h}=400 \& \mathrm{o}=\mathrm{a} \& \mathrm{uc}=0 \& \mathrm{by}=$ $2013 \& \mathrm{bm}=1 \& \mathrm{bd}=3 \& \mathrm{bh}=6 \&$ ey $=2013 \& \mathrm{em}=1 \& \mathrm{ed}=23 \& \mathrm{eh}=$ $6 \&$ data $=0 \&$ units $=0 \&$ region $=$ us.

National Oceanic and Atmospheric Administration, 2015a, Quality controlled local climatological data, Mansfield LAHN regional airport: National Centers for Environmental Information Web page accessed on August 7, 2015, at http:// www.ncdc.noaa.gov/qclcd/QCLCD.

National Oceanic and Atmospheric Administration, 2015b, National snow analysis: National Weather Service, National Operational Hydrologic Remote Sensing Center Web page, accessed on June 29, 2015 at http://www.nohrsc. noaa.gov/nsa/. 
Ohio Geographically Referenced Information Program, 2006, Ohio statewide imagery program: Ohio Geographically Referenced Information Program Web page, accessed on October 2, 2014, at http://ogrip.oit.ohio.gov/projectsinitiatives/statewideimagery.aspx.

Price, M.A., 1998, Seasonal variation in runoff curve numbers: Master's Thesis, University of Arizona, 189 p.

Rantz, S.E., and others, 1982, Measurement and computation of streamflow, Volume 1, Measurement of stage and discharge, and Volume 2, Computation of discharge: U.S. Geological Survey Water-Supply Paper 2175, 631 p.

Straub, D.E., Ebner, A.D., and Astifan, B.M., 2009, Floods of August 21-24, 2007, in northwestern and northcentral Ohio: U.S. Geological Survey Open-File Report 2009-1094, 76 p.

U.S. Army Corps of Engineers, 2000, Hydrologic modeling system HEC-HMS, technical reference manual: Hydrologic Engineering Center Report CPD-74B, 149 p.

U.S. Army Corps of Engineers, 2010a, HEC-RAS river analysis system, user's manual, version 4.1: Hydrologic Engineering Center Report CPD-68, 790 p.

U.S. Army Corps of Engineers, 2010b, HEC-RAS river analysis system, hydraulic reference manual, version 4.1: Hydrologic Engineering Center Report CPD-69, 417 p.

U.S. Army Corps of Engineers, 2010c, HEC-RAS river analysis system, applications guide, version 4.1: Hydrologic Engineering Center Report CPD-70, 351 p.

U.S. Army Corps of Engineers, 2010d, Geospatial hydrologic modeling extension, HEC-GeoHMS, user's manual, version 10.0: Hydrologic Engineering Center Report CPD-77, $197 \mathrm{p}$.

U.S. Army Corps of Engineers, 2013, Hydrologic modeling system, HEC-HMS, user's manual, version 4.0: Hydrologic Engineering Center Report CPD-74A, 442 p.

U.S. Census Bureau, 2011, State \& county quickfacts, Shelby (city), Ohio, Population, 2010: U.S. Census Bureau Web page, accessed on November 9, 2011, at http://quickfacts. census.gov/qfd/states/39/3972102.html.
U.S. Department of Agriculture, 1987, Flood plain management study, Black Fork of Mohican River and tributaries, Richland County, Ohio, January 1987: Soil Conservation Service, [variously paged].

U.S. Department of Agriculture, 2004, Part 630 hydrology national engineering handbook, chapter 10, Estimation of direct runoff from storm rainfall: Natural Resources Conservation Service Report 210-VI-NEH, 79 p., accessed on August 31, 2015, at http://www.wcc.nrcs.usda.gov/ftpref/ wntsc/H\&H/NEHhydrology/ch10.pdf.

U. S. Department of Agriculture, 2015, Web soil survey: Natural Resources Conservation Service Web page, accessed on June 29, 2015 at http://websoilsurvey.nrcs.usda.gov/.

U.S. Geological Survey, 2014, Global navigation satellite system, real-time network (RTN) surveying: Global Navigation Satellite System Web page, accessed June 29, 2015, at http://water.usgs.gov/osw/gps/real-time_network.html.

U.S. Geological Survey, 2015a, National water information system, Web interface: USGS 03129197 Black Fork Mohican River at Shelby OH: National Water Information System Web page, accessed August 21, 2015, at http://waterdata.usgs.gov/nwis/inventory/?site no=03129197\&agency_cd=USGS.

U.S. Geological Survey, 2015b, National water information system, web interface: USGS 405209082393200 Rain Gage at Reservoir Number Two at Shelby OH: National Water Information System Web page accessed August 21, 2015, at http://waterdata.usgs.gov/nwis/inventory/?site no $=405209082393200$ \&agency_cd=USGS.

Van Mullem, J., Woodward, D.E., Hawkins, R.H., Hjelmfelt, A.T., 2002, Runoff curve umber method: Beyond the handbook, in, Second Federal Interagency Hydrologic Modeling Conference, July 28-August 1, 2002, Las Vegas, Nevada, p. 1713-1722, accessed August 21, 2015, at http://acwi. gov/hydrology/mtsconfwkshops/conf_proceedings/second_ fihmc_nevada.pdf. 


\section{Appendixes}

\section{Appendix 1. Tables Showing HEC-RAS Output for Selected Stream Reaches in and near Shelby, Ohio}

[Appendix 1 may be downloaded as a separate file at http://dx.doi.org/2015/5187]

\section{Appendix 2. Graphs Showing Computed Water-surface Pro- files for the 10-, 2-, 1-, and 0.2-Percent Annual-exceedance Probability Flood-peak Discharges and Floodway for Five Selected Stream Reaches in and near Shelby, Ohio}

2-1a-d. Computed water-surface profiles for the 10-, 2-, 1-, and 0.2-percent annual-exceedance probability (AEP) flood-peak discharges and floodway for Black Fork Mohican River, in and near Shelby, Ohio.

2-2a-c. Computed water-surface profiles for the 10-, 2-, 1-, and 0.2-percent annual-exceedance probability (AEP) flood-peak discharges and floodway for Seltzer Park Creek, in and near Shelby, Ohio.

2-3. Computed water-surface profiles for the 10-, 2-, 1-, and 0.2-percent annual-exceedance probability (AEP) flood-peak discharges and floodway for Seltzer Park Tributary, in and near Shelby, Ohio.

2-4a-b. Computed water-surface profiles for the 10-, 2-, 1-, and 0.2-percent annual-exceedance probability (AEP) flood-peak discharges and floodway for Tuby Run, in and near Shelby, Ohio.

2-5. Computed water-surface profiles for the 10-, 2-, 1-, and 0.2-percent annual-exceedance probability (AEP) flood-peak discharges and floodway for West Branch, in and near Shelby, Ohio. 


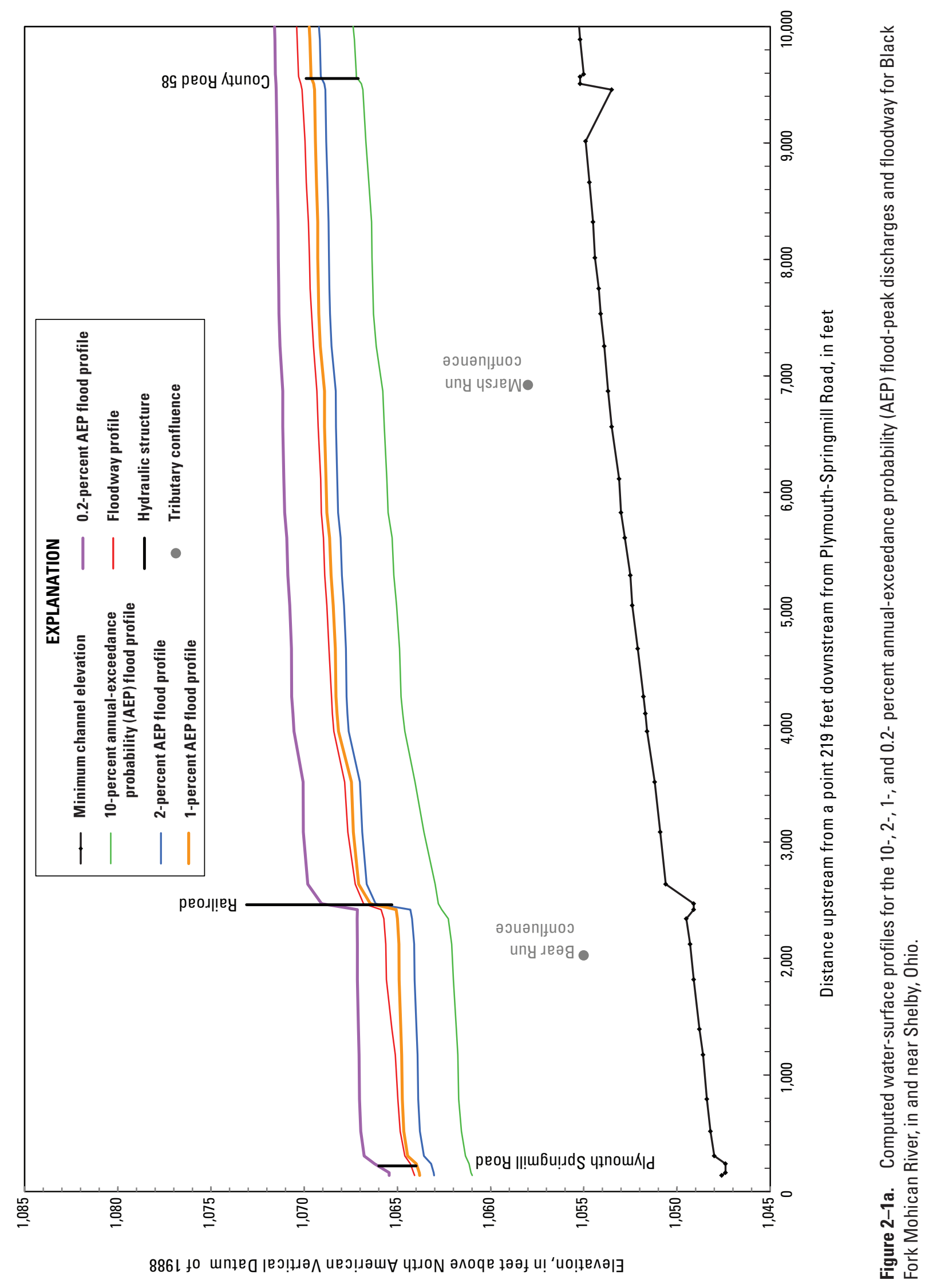




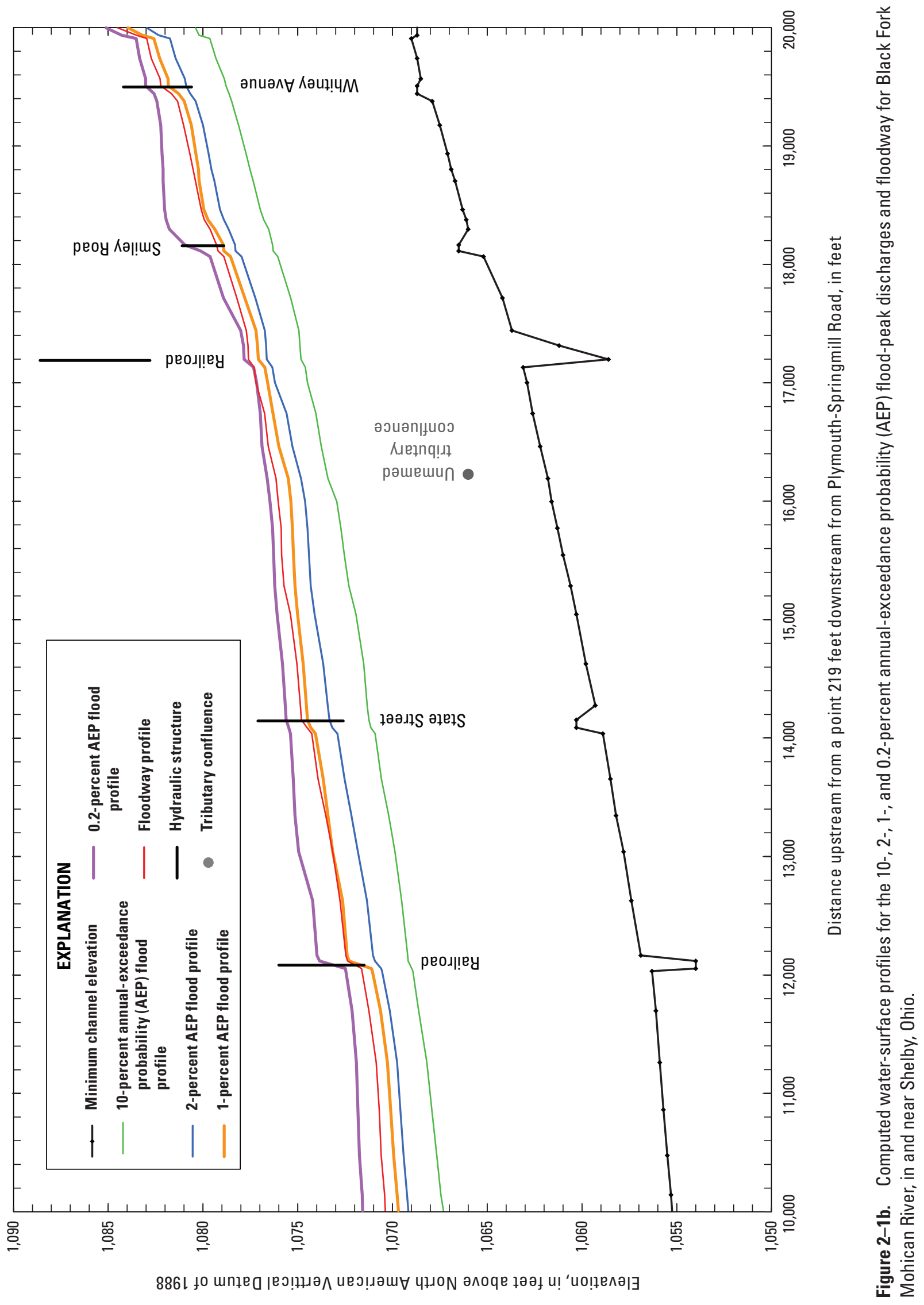




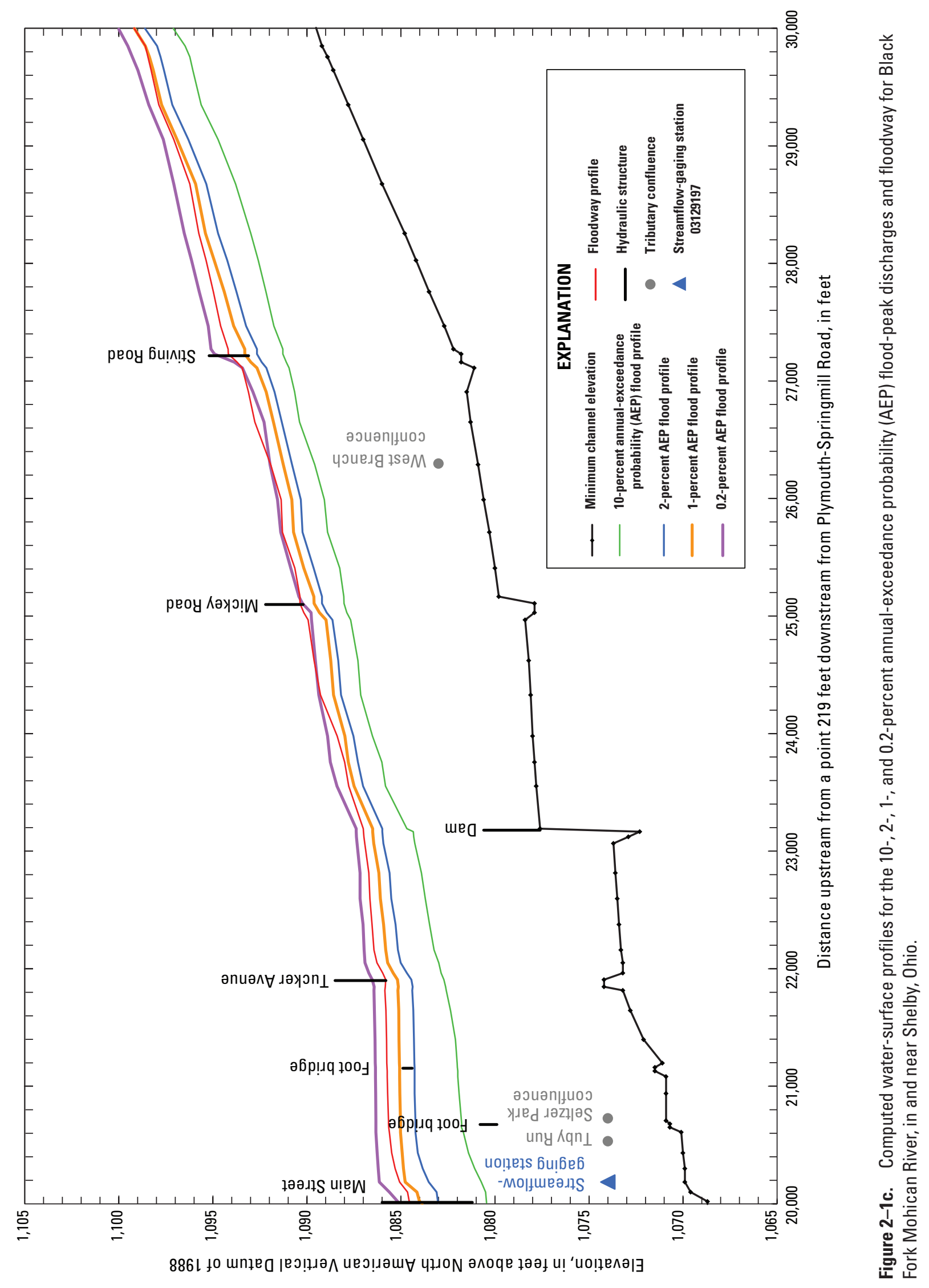



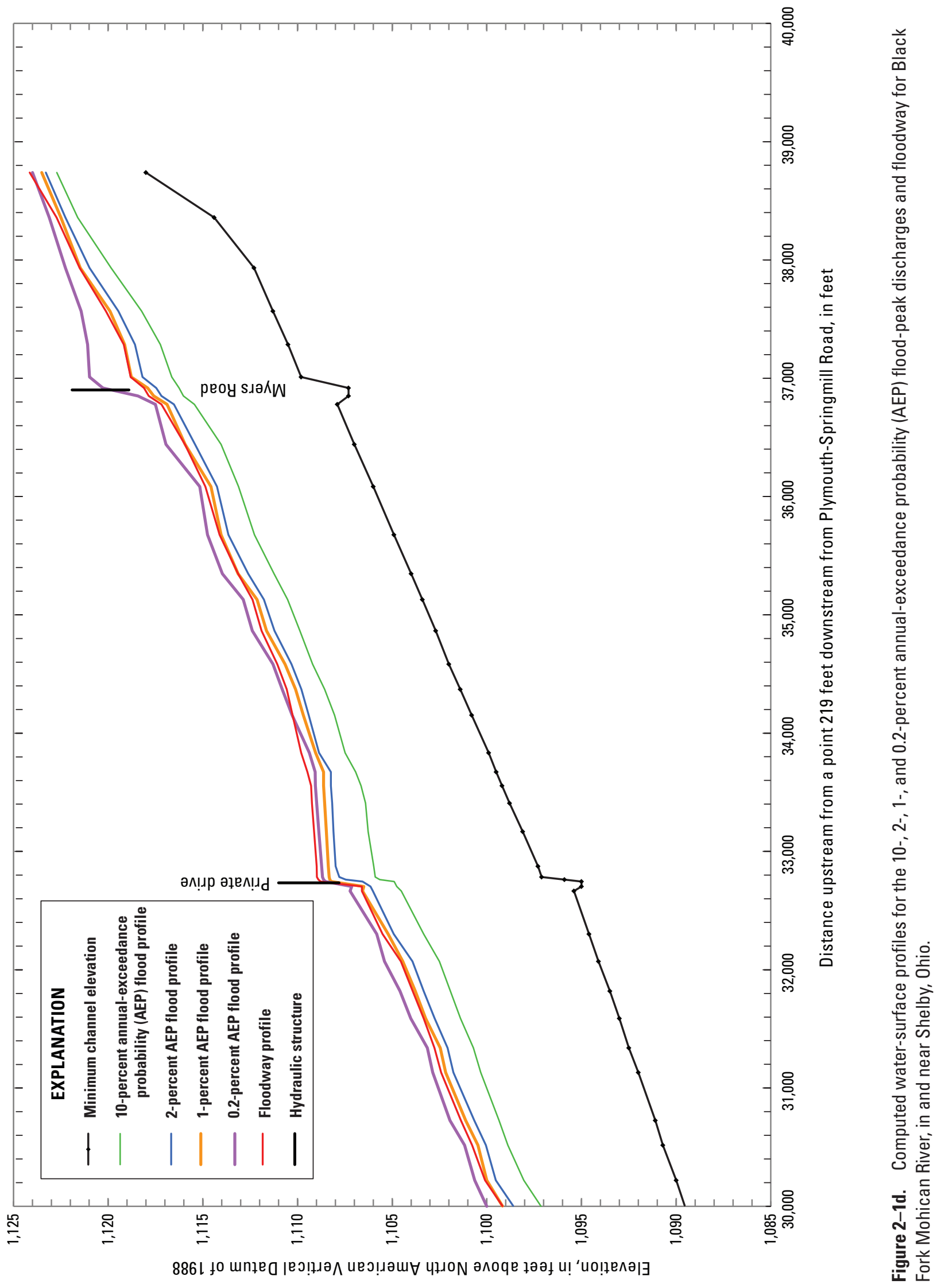


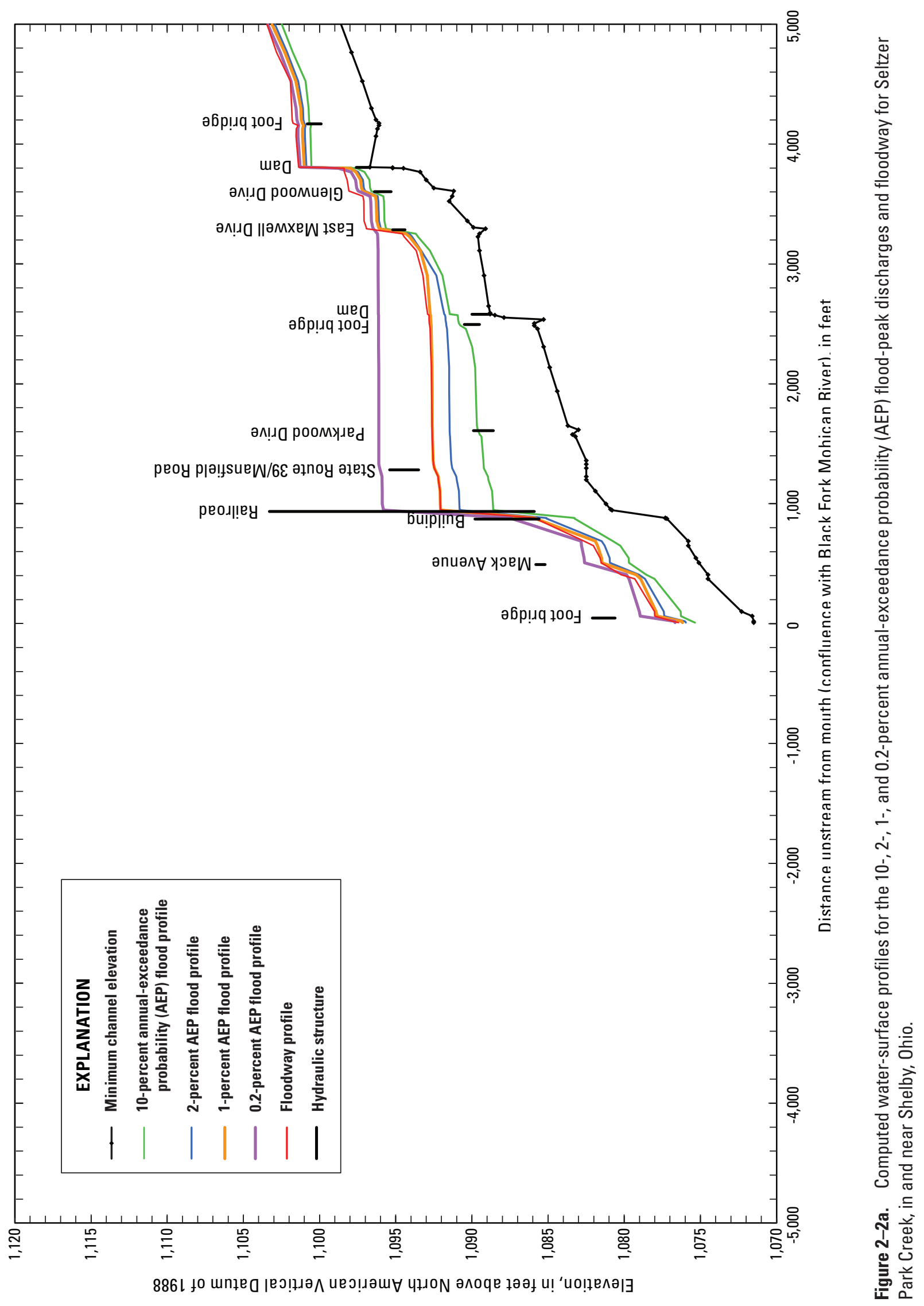




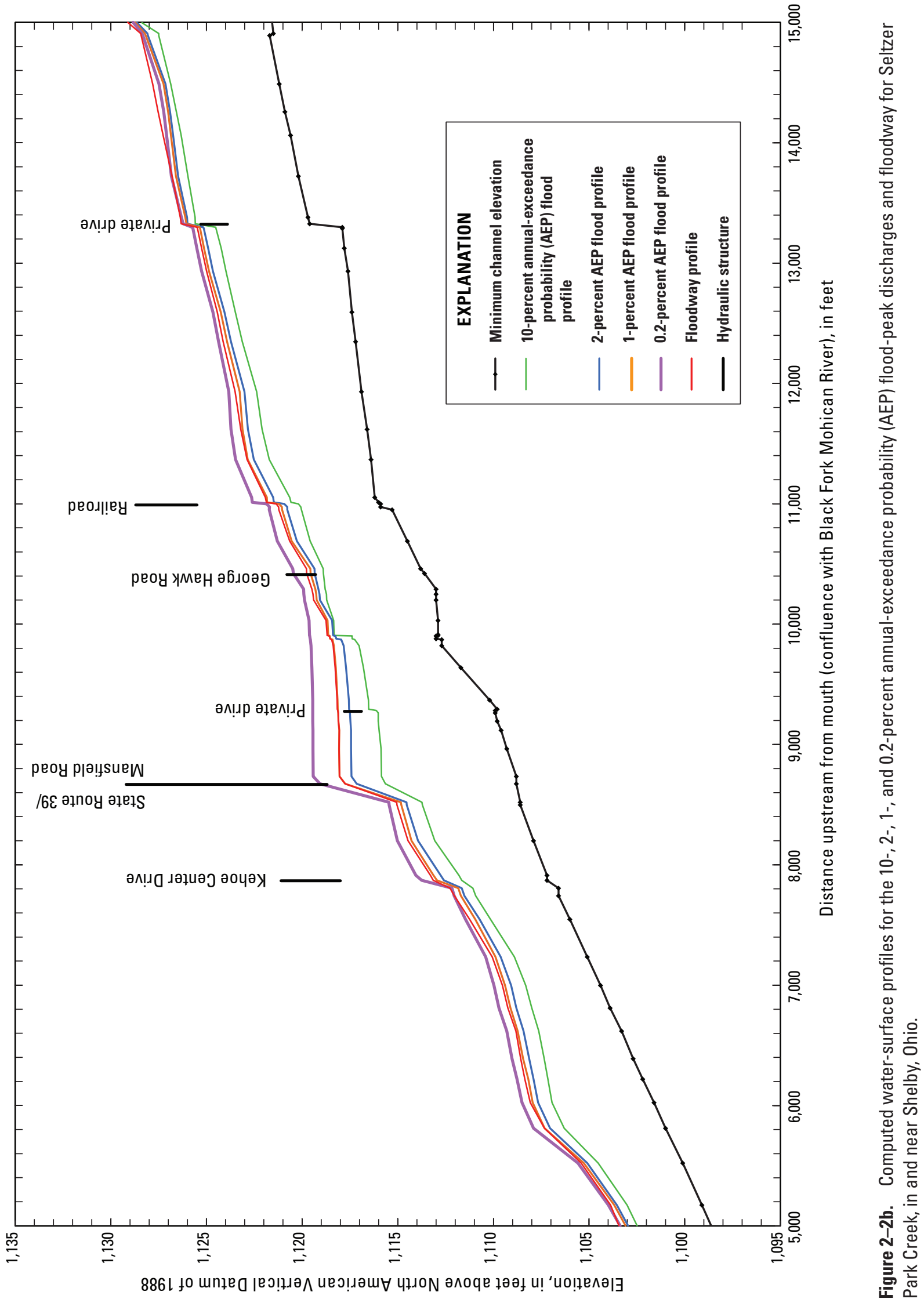




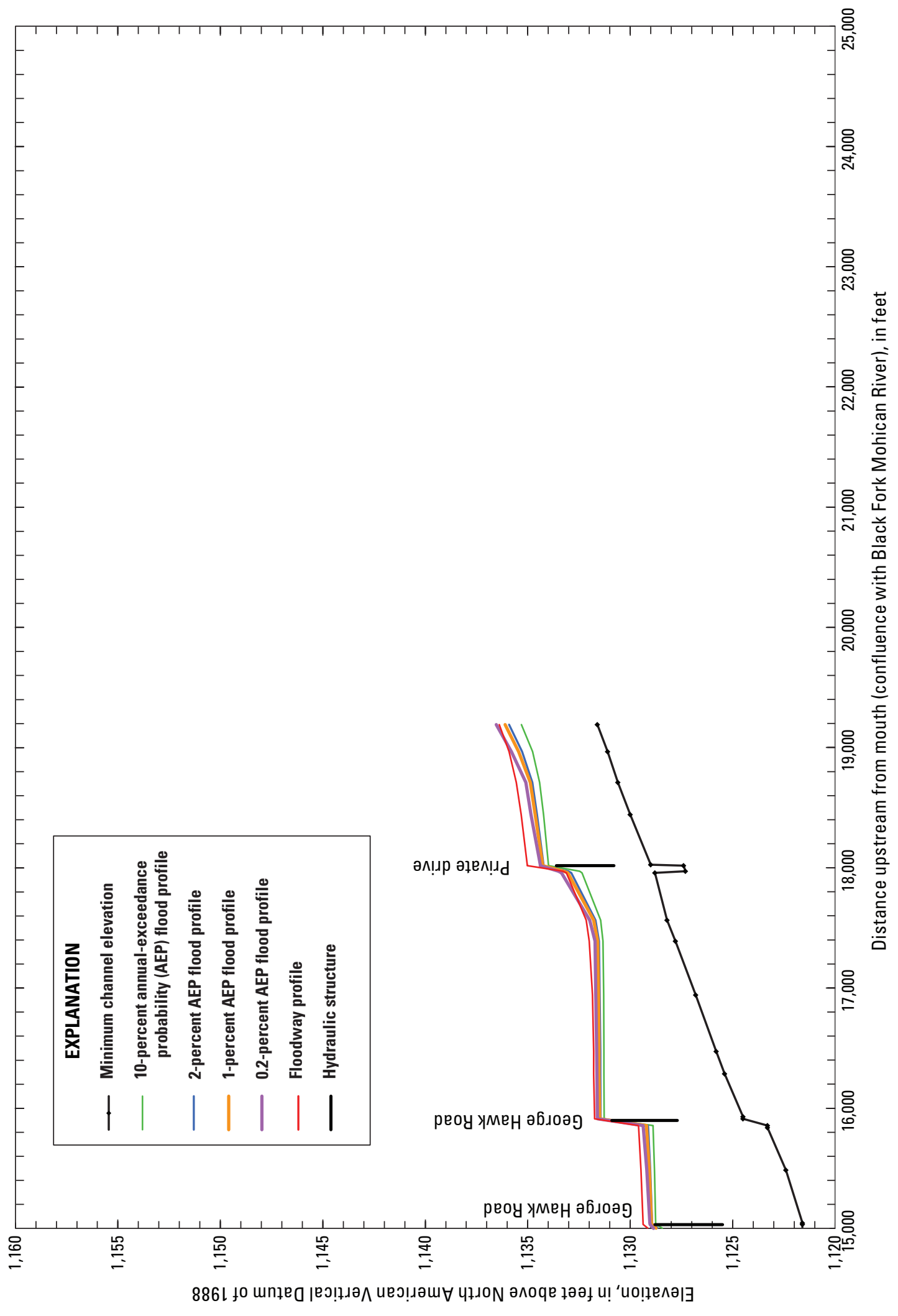

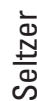

产

은

ส

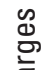

$\frac{\pi}{0}$

$\stackrel{\frac{1}{2}}{2}$ 


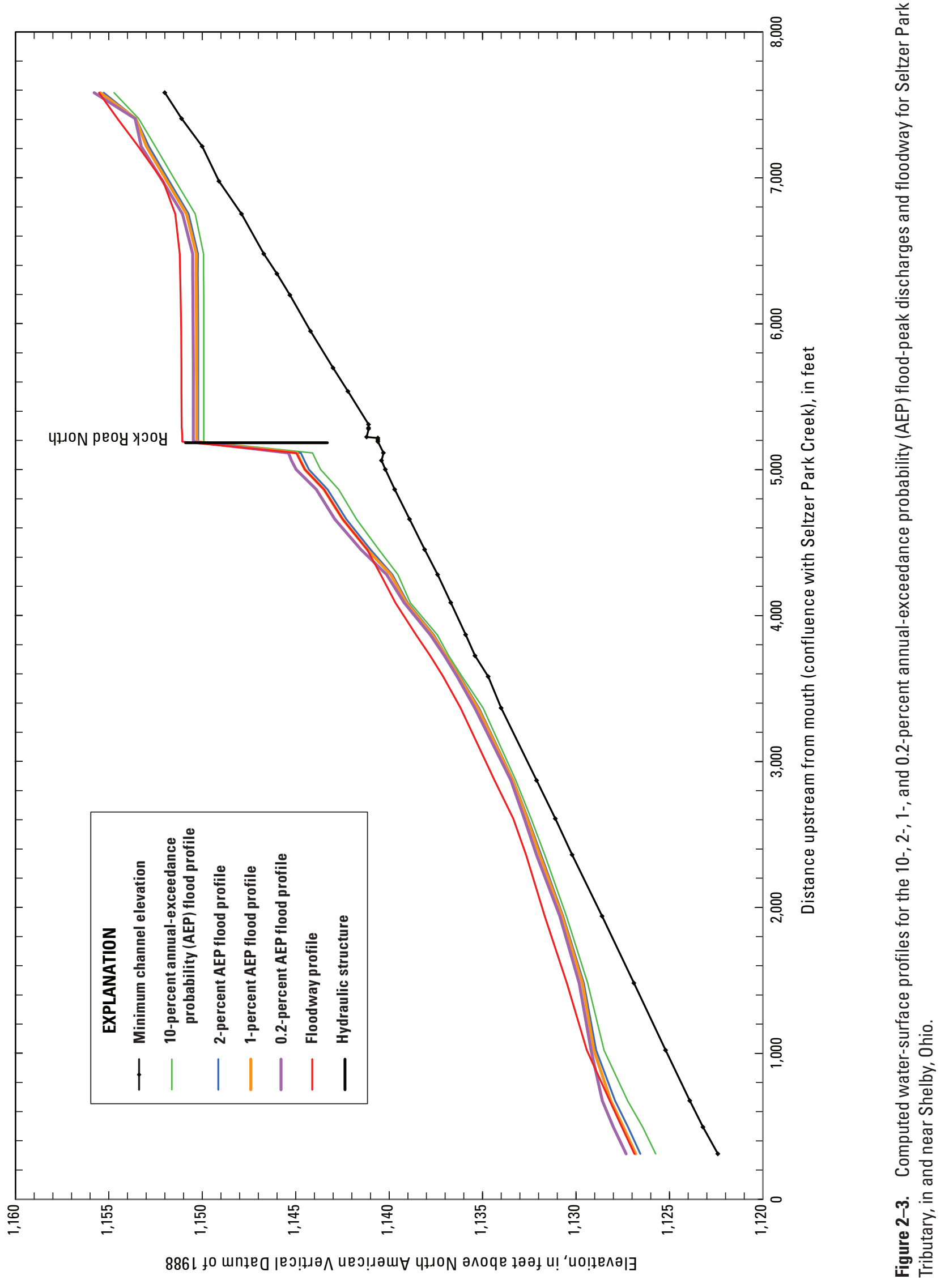




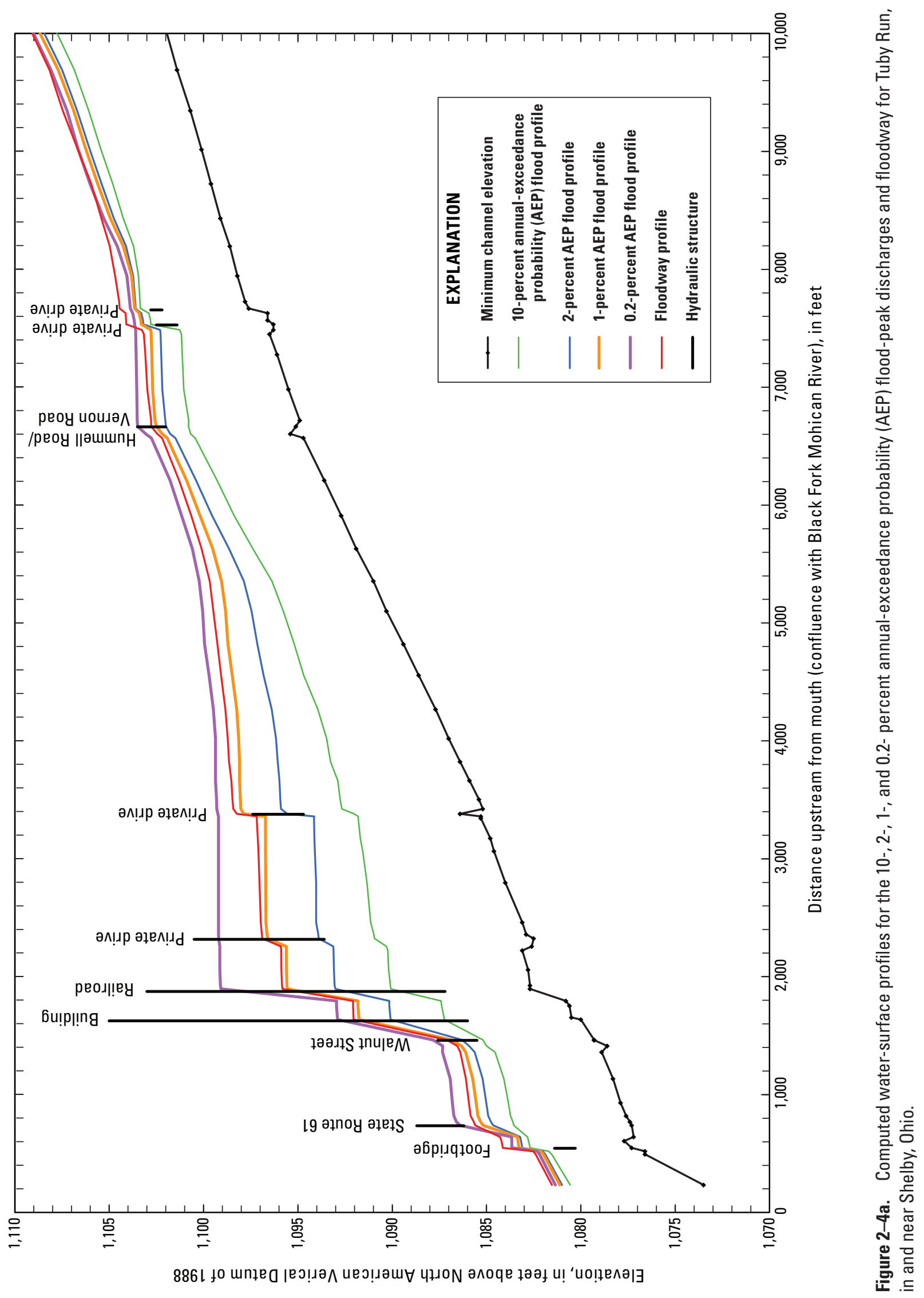




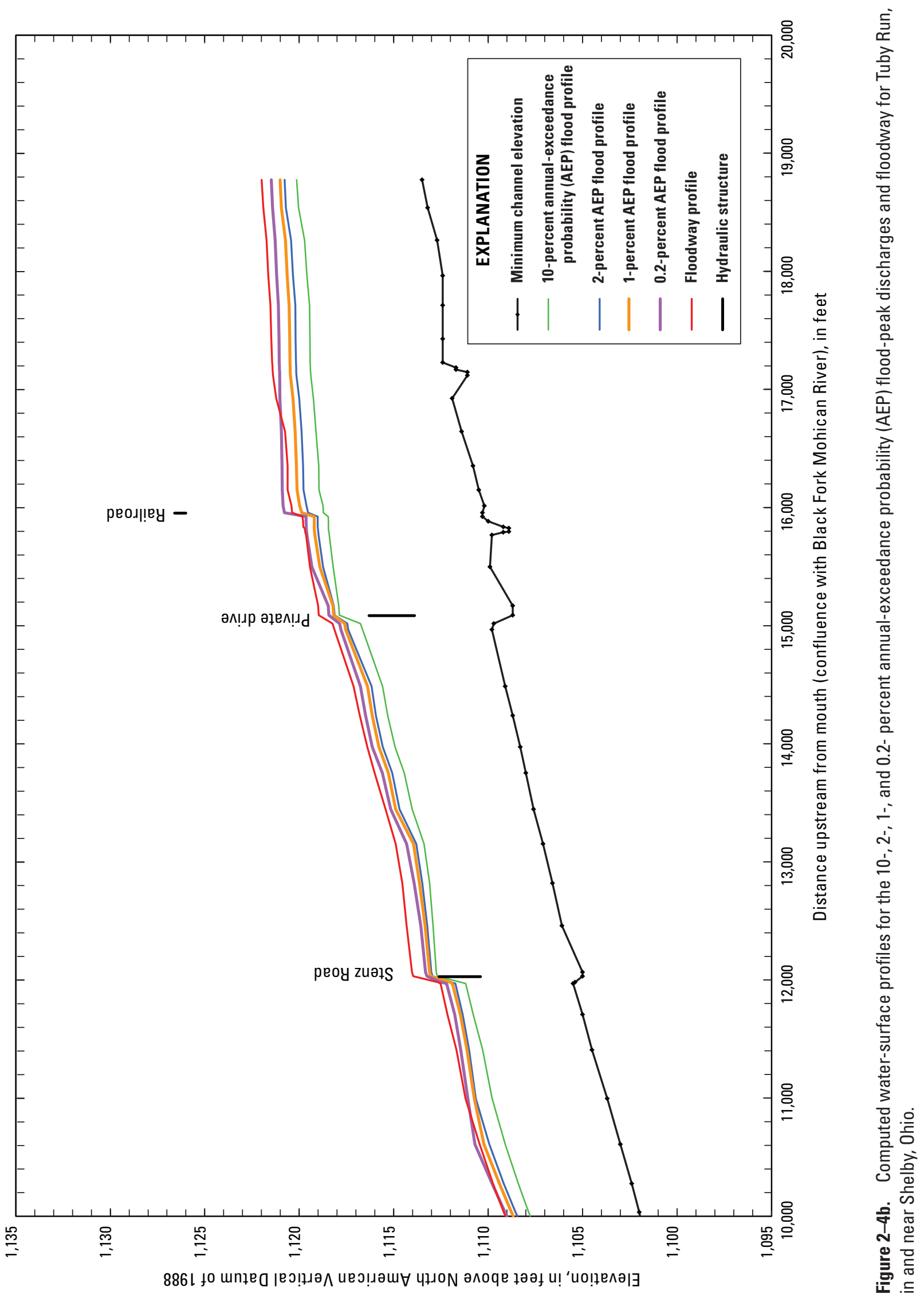




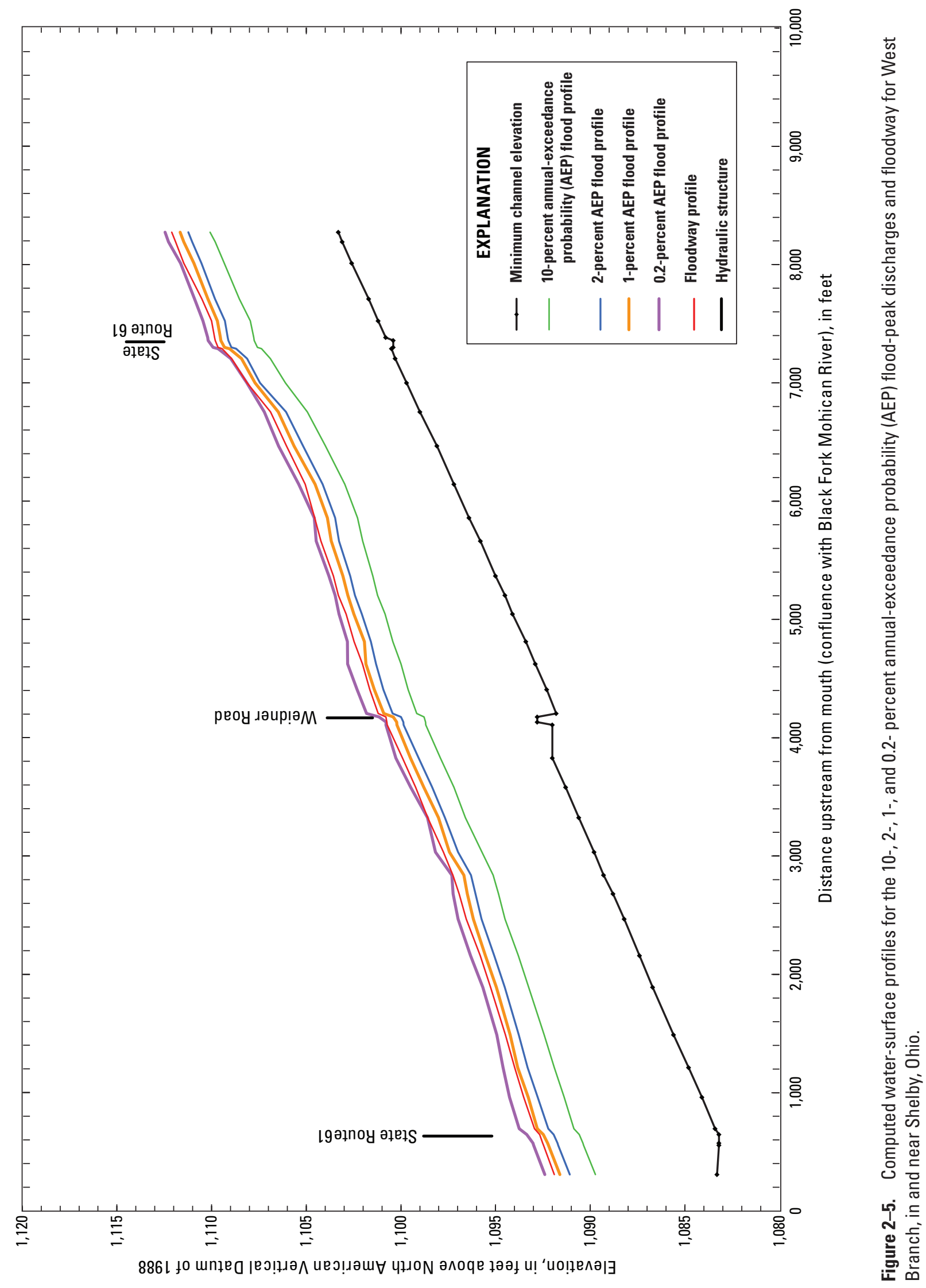




\section{Appendix 3. Precipitation-runoff Model Parameters, Event Data Collected, and Results for the Black Fork Mohican River Basin}

\section{Figures}

3-1. Screen shot from HEC-HMS precipitation-runoff model showing the temperature index parameter values used for the December 2013 event (model run 11).

3-2. Screen shot from HEC-HMS precipitation-runoff model showing the temperature index parameter values used for the February 2014 event (model run 12).

3-3. Graph showing snow water equivalent, snow depth, and snow melt for station MFD-LAHM Municipal Airport, Mansfield, Ohio, for December 3-23, 2013 (National Oceanic and Atmospheric Administration, 2014a).

3-4. Graph showing snow water equivalent, snow depth, and snow melt for station MFD-LAHM Municipal Airport, Mansfield, Ohio, for February 1-23, 2014 (National Oceanic and Atmospheric Administration, 2014a).

3-5. Graph showing snow water equivalent, snow depth, and snow melt for station OH-SN-3- Tiffin 5.2 SE, Ohio, for February 1-26, 2014 (National Oceanic and Atmospheric Administration, 2014b).

3-6. Plot from the HEC-HMS precipitation-runoff model, run 8, showing observed and simulated streamflows at the Black Fork Mohican River at Shelby, Ohio, (U.S. Geological Survey streamflow-gaging station 03129197) during April 10-15, 2013.

3-7. Plot from the HEC-HMS precipitation-runoff model, run 9, showing observed and simulated streamflows at the Black Fork Mohican River at Shelby, Ohio, (U.S. Geological Survey streamflow-gaging station 03129197) during June 12-15, 2013.

3-8. Plot showing the cumulative precipitation observed at the U.S. Geological Survey precipitation gage at Reservoir Number Two, at Shelby, Ohio (405209082393200), during July 4-12, 2013.

3-9. Plot from HEC-HMS precipitation-runoff model, run 10, showing observed and simulated streamflows at the Black Fork Mohican River at Shelby, Ohio (U.S. Geological Survey streamflow-gaging station 03129197), during July 7-12, 2013.

3-10. Plot from HEC-HMS precipitation-runoff model, run 11, showing observed and simulated streamflows at the Black Fork Mohican River at Shelby, Ohio (U.S. Geological Survey streamflow-gaging station 03129197), during December 20-26, 2013.

3-11. Plot from HEC-HMS precipitation-runoff model, run 12, showing observed and simulated streamflows at the Black Fork Mohican River at Shelby, Ohio (U.S. Geological Survey streamflow-gaging station 03129197), during February 19-25, 2014. 


\section{Tables}

3-1. Values from the HEC-HMS precipitation-runoff model antecedent temperature index (ATI) melt-rate function used for the winter-period model, during the December 2013 and February 2014 events.

3-2. Values from the HEC-HMS precipitation-runoff model antecedent temperature index (ATI) cold-rate function used for the winter-period model, during the December 2013 and February 2014 events.

3-3. Instantaneous streamflow measurements taken at Black Fork Mohican River at Shelby, Ohio (U.S. Geological Survey streamflow-gaging station 03129197), on July 9, 2013, during the recession of the hydrograph.

3-4. Precipitation and temperature data obtained at the Mansfield, Ohio airport (MFD) from December 18-23, 2013.

3-5. Precipitation and temperature data obtained at the Mansfield, Ohio airport (MFD) from February 17-21, 2014. 


\section{Precipitation-runoff Model Parameters and Event Data Collected}

The U.S. Army Corps of Engineers Hydrologic Engineering Center-Hydrologic Modeling System (USACE HECHMS) version $4.0(2000,2013)$ was used to develop precipitation-runoff models for the Black Fork Mohican River basin; precipitation, streamflow, and water-level data were collected from July 2012 through August 2014 for model inputs and calibration. Two models were developed, one for winter period events and one for nonwinter period events. The winter-period model was calibrated and verified using two events:

December 22, 2013 (run 11), and February 21, 2014 (run 12). The nonwinter period model was calibrated and verified using three events: April 12, 2013 (run 8); June 13, 2013 (run 9); and July 9, 2013 (run 10).
Two of the winter-period peak events (model runs 11 and 12) were snowmelt and rain-on-snow events. These events were modeled using the temperature index method to compute the amount of snowpack melt for each degree above freezing, and the subbasin band approach (U.S. Army Corps of Engineers, 2013). The same temperature index parameter values were used for both of the snowpack melt events; only the wet melt rate was different for each event. The wet melt rates represent the rate at which the snowpack melts when it is raining on the snowpack and are used during time intervals when precipitation is falling as rain (U.S. Army Corps of Engineers, 2013). The wet melt rates used for the December 22, 2013, and February 21, 2014, events were 0.23 and 0.76 inches per degrees Fahrenheit-day (in $/{ }^{\circ} \mathrm{F}$ day), respectively. Figures 3-1 and 3-2 show the temperature index parameters used in HEC-HMS for the December 2013 (model run 11) and February 2014 (model run 12) events.

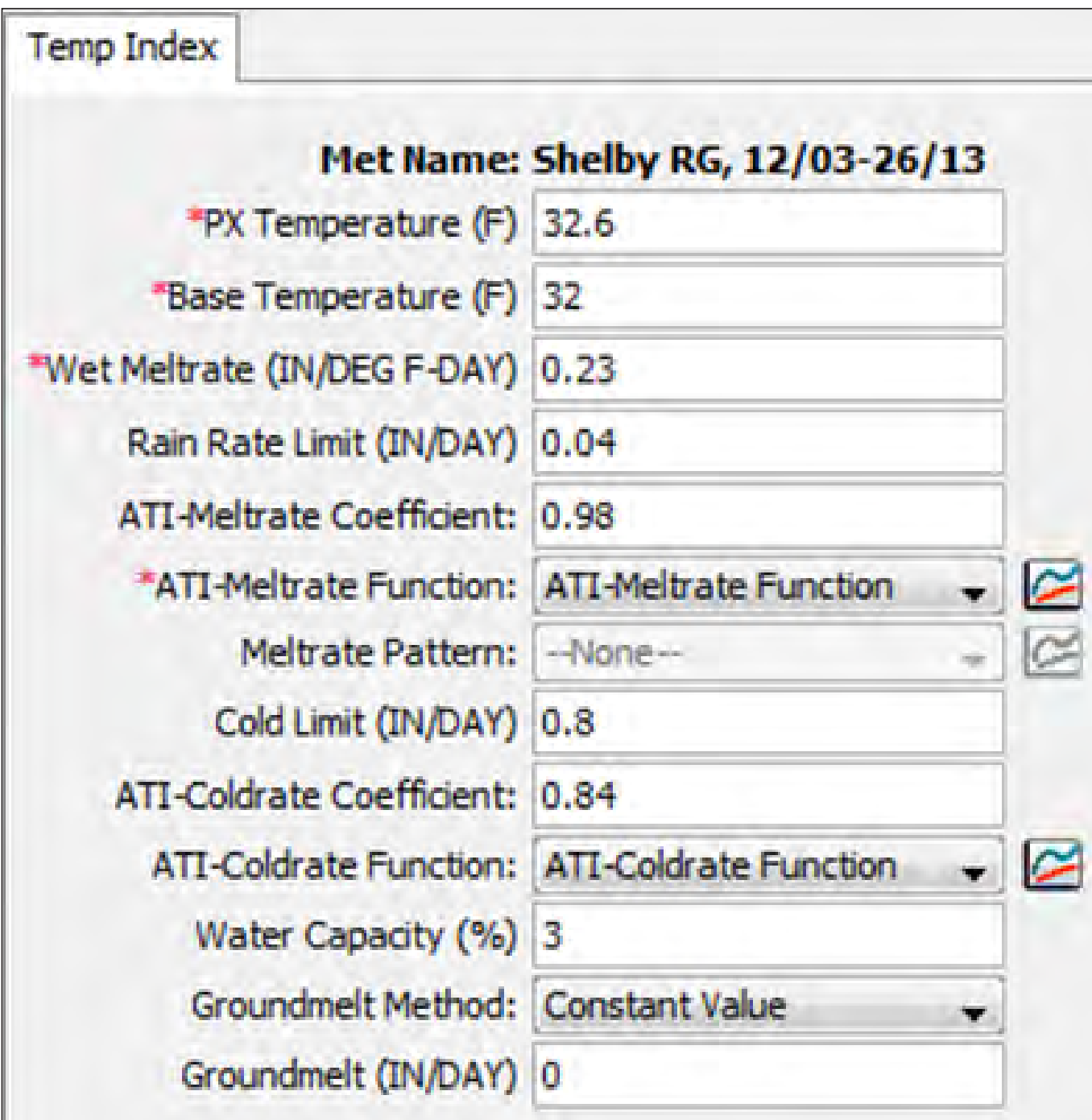

Figure 3-1. Screen shot from HEC-HMS precipitation-runoff model showing the temperature index parameter values used for the December 2013 event (model run 11). 


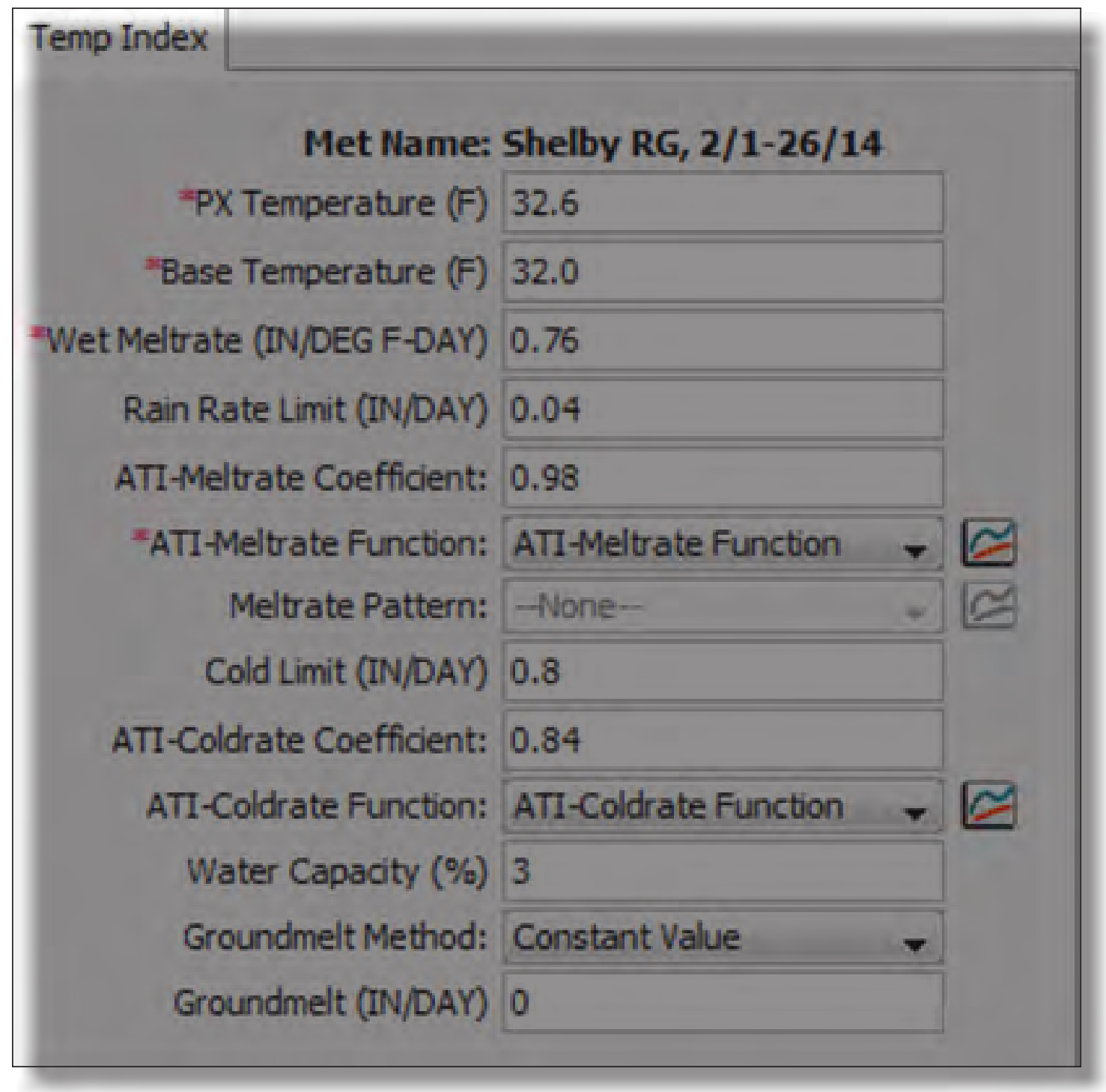

Figure 3-2. Screen shot from HEC-HMS precipitation-runoff model showing the temperature index parameter values used for the February 2014 event (model run 12).

The same antecedent temperature index (ATI) melt-rate function values were used to calculate a melt rate from the current melt rate index; ATI cold-rate function values were used to update the antecedent cold content index from one time interval to the next (U.S. Army Corps of Engineers, 2013) (tables 3-1 and 3-2) for both winter-period events.

The HEC-HMS model constructed for the Black Fork Mohican River basin contains 21 reaches and 40 subbasins ranging in area from 0.001 to 4.062 square miles $\left(\mathrm{mi}^{2}\right)$. Each subbasin includes the parameter data to calculate the air temperatures at different elevation bands (U.S. Army Corps of Engineers, 2013). Both winter-period events modeled use the same lapse rate of $-3.5^{\circ} \mathrm{F} / 1,000$ feet (ft) with only one subbasin elevation band (due to the flat terrain of all of the subbasins modeled). An initial snow water equivalent (SWE) in inches was assigned to each subbasin to simulate the starting conditions. These starting conditions are difficult to estimate because no data were collected within the basin for snow depth and SWE. The closest sites to Shelby with snow data were located at the Mansfield LAHM regional airport station number 14891/MFD (National Oceanic and Atmospheric Administration, 2015a) and in Tiffin station number OH-SN-3, approximately 8 miles (mi) southeast, and $26.6 \mathrm{mi}$ west-northwest of Shelby, respectively. Snow depth and SWE data were collected by the National Oceanic and Atmospheric Administration (NOAA) (National Oceanic and Atmospheric Administration, National Operational Hydrologic Remote Sensing Center [NOHRSC] Interactive Snow Information 2015a, b). By use of the data from the Mansfield and Tiffin sites, it was determined that there was no snow accumulation at the start of the December 2013 event, which resulted in the initial SWE for the subbasins of 0.0 (fig. 3-3). 
Table 3-1. Values from the HEC-HMS precipitation-runoff model antecedent temperature index (ATI) melt-rate function used for the winter-period model, during the December 2013 and February 2014 events.

[HEC-HMS, Hydrologic Engineering Center-Hydrologic Modeling System; inches/Degree F-Day, inches per degrees Fahrenheit-day]

\begin{tabular}{lc}
\hline ATI (Degree F-Day) & Meltrate (Inches/Degree F-Day) \\
\hline 0 & 0.025 \\
100 & 0.030 \\
200 & 0.050 \\
\hline
\end{tabular}

Table 3-2. Values from the HEC-HMS precipitation-runoff model antecedent temperature index (ATI) cold-rate function used for the winter-period model, during the December 2013 and February 2014 events.

[HEC-HMS, Hydrologic Engineering Center-Hydrologic Modeling System; inches/Degree F-Day, inches per degrees Fahrenheit-day]

\begin{tabular}{lc}
\hline ATI (Degree F-Day) & Coldrate (Inches/Degree F-Day) \\
\hline 0 & 0.0480 \\
100 & 0.0480 \\
200 & 0.0519 \\
\hline
\end{tabular}

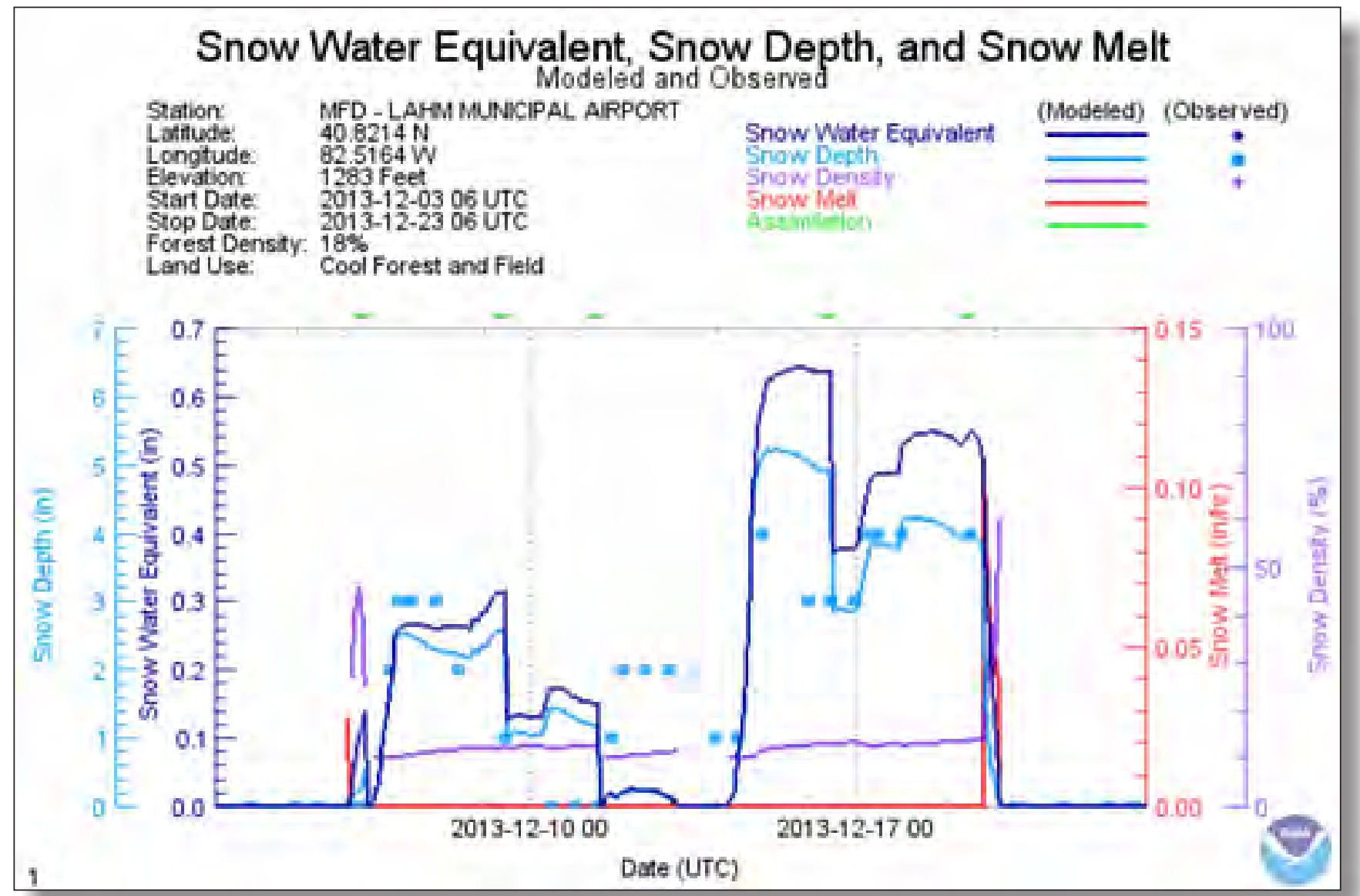

Figure 3-3. Graph showing snow water equivalent, snow depth, and snow melt for station MFD-LAHM Municipal Airport, Mansfield, Ohio for December 3-23, 2013 (National Oceanic and Atmospheric Administration, 2014a). 
The initial SWE for the February 2014 event was difficult to estimate because different values were reported for the two sites. Mansfield (MFD) had an observed snow depth of 1.1 inches (in.) and a modeled snow depth of 1.5 in., resulting in a modeled SWE of 0.2 in. on February 1. Tiffin (OH-SN-3) had an observed snow depth of $3.6 \mathrm{in}$. and modeled snow depth of 6 in., resulting in a modeled SWE of $0.9 \mathrm{in}$. An approximate factor of 0.15 times the modeled snow depth was used for both locations to obtain the SWE for February 1, 2014. For model input, an average SWE was computed based on the observed snow depths for the two sites and was used for the start of the event on February 1, 2014. The observed snow depths of 1.1 in. and 3.6 in. resulted in an average snow depth of 2.35 in., and application of the factor of 0.15 times the snow depth resulted in SWE of 0.35 in. for the initial conditions in each subbasin. Figures 3-4 and 3-5 show SWE, snow depth, snow density, and snow melt data for the Mansfield and Tiffin sites, respectively, for the February 2014 event.

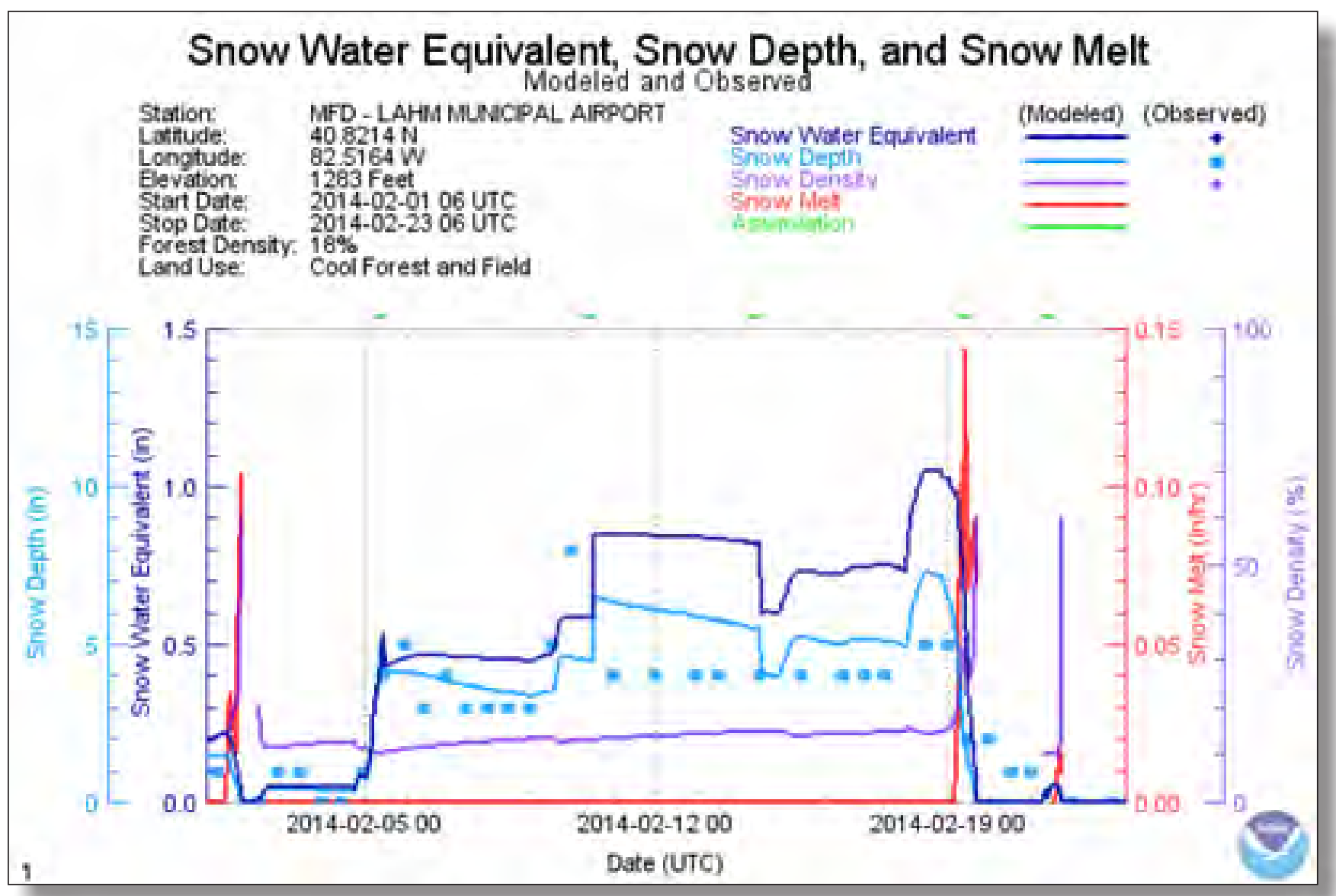

Figure 3-4. Graph showing snow water equivalent, snow depth, and snow melt for station MFD-LAHM Municipal Airport, Mansfield, Ohio, for February 1-23, 2014 (National Oceanic and Atmospheric Administration, 2014a). 


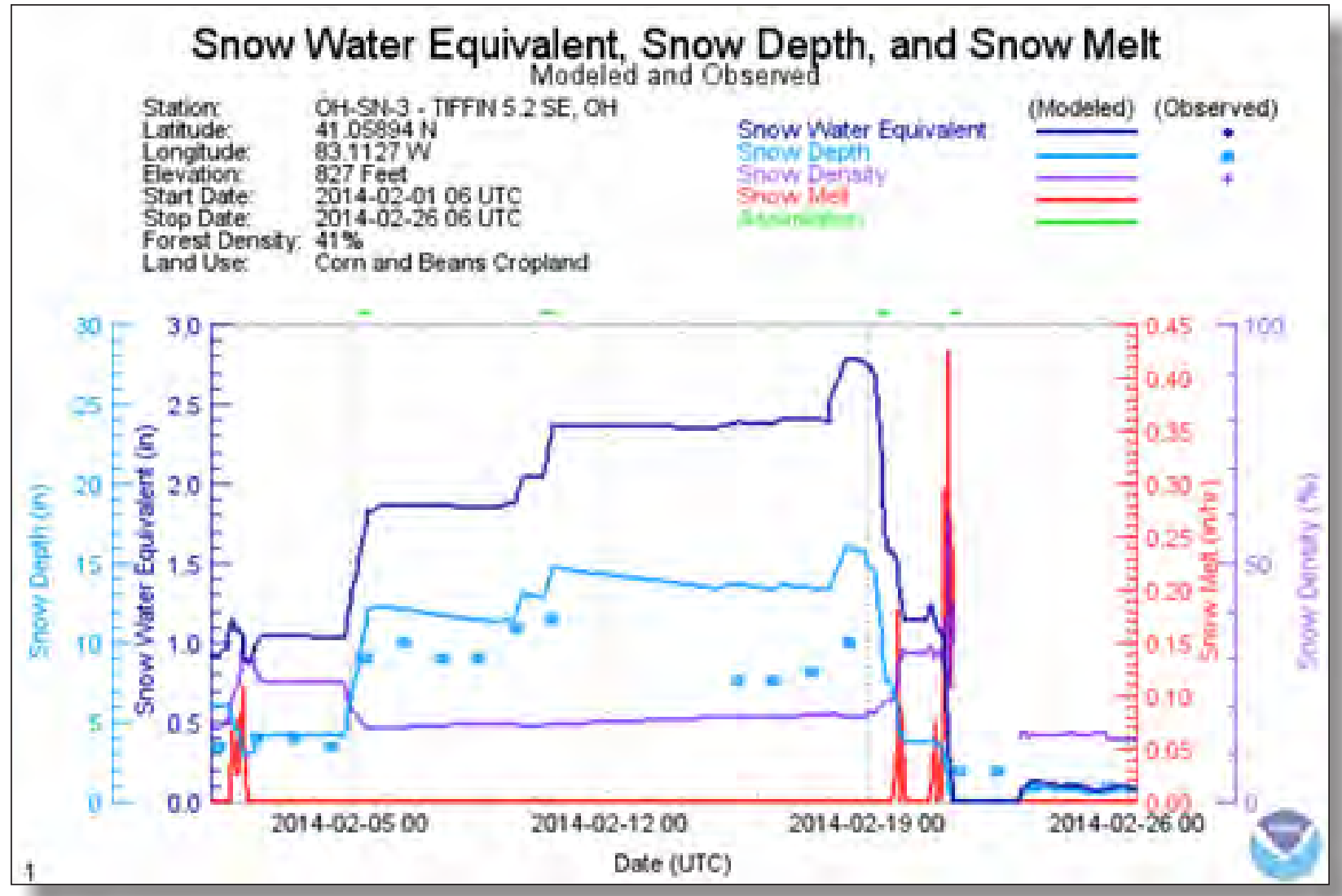

Figure 3-5. Graph showing snow water equivalent, snow depth, and snow melt for station $\mathrm{OH}-\mathrm{SN}-3-\mathrm{Tiffin} 5.2 \mathrm{SE}$, Ohio, for February 1-26, 2014 (National Oceanic and Atmospheric Administration, 2014b). 


\section{HEC-HMS Runoff Event Results}

A runoff event (hereafter referred to as an "event") can occur as a result of rainfall, snowmelt, or both. The event on April 12, 2013, resulted in an observed peak gage height of $12.0 \mathrm{ft}(1,077.3 \mathrm{ft}$ NAVD 88) at 03:00 Eastern Daylight Time (EDT) with an associated discharge of 1,250 cubic feet per second $\left(\mathrm{ft}^{3} / \mathrm{s}\right)$ at the Black Fork Mohican River at Shelby streamflow-gaging station (03129197). The HEC-HMS simulation for this event (model run 8) commenced on March 8 and continued through April 15. The antecedent conditions were dry (no rain measured at the Rain Gage at Reservoir Number
Two at Shelby [405209082393200] 15 days prior to the event). The precipitation gage data (405209082393200) indicate that most of the rain that contributed to the peak flows fell between April 10 at 16:15 EDT and April 12 at 07:00 EDT. Approximately 3.24 in. of rain fell in 39 hours. Figure 3-6 shows the observed (black line with points) and simulated (blue line) streamflows at streamflow-gaging station 03129197 (UserPoint2, in HEC-HMS) for the April 10-15, 2013, period. The first observed peak on April 10-11 is close in timing and peak flow to the simulated peak (fig. 3-6), but streamflow rates and runoff volume are underestimated in the recession. The largest spread between observed and simulated streamflows occurred

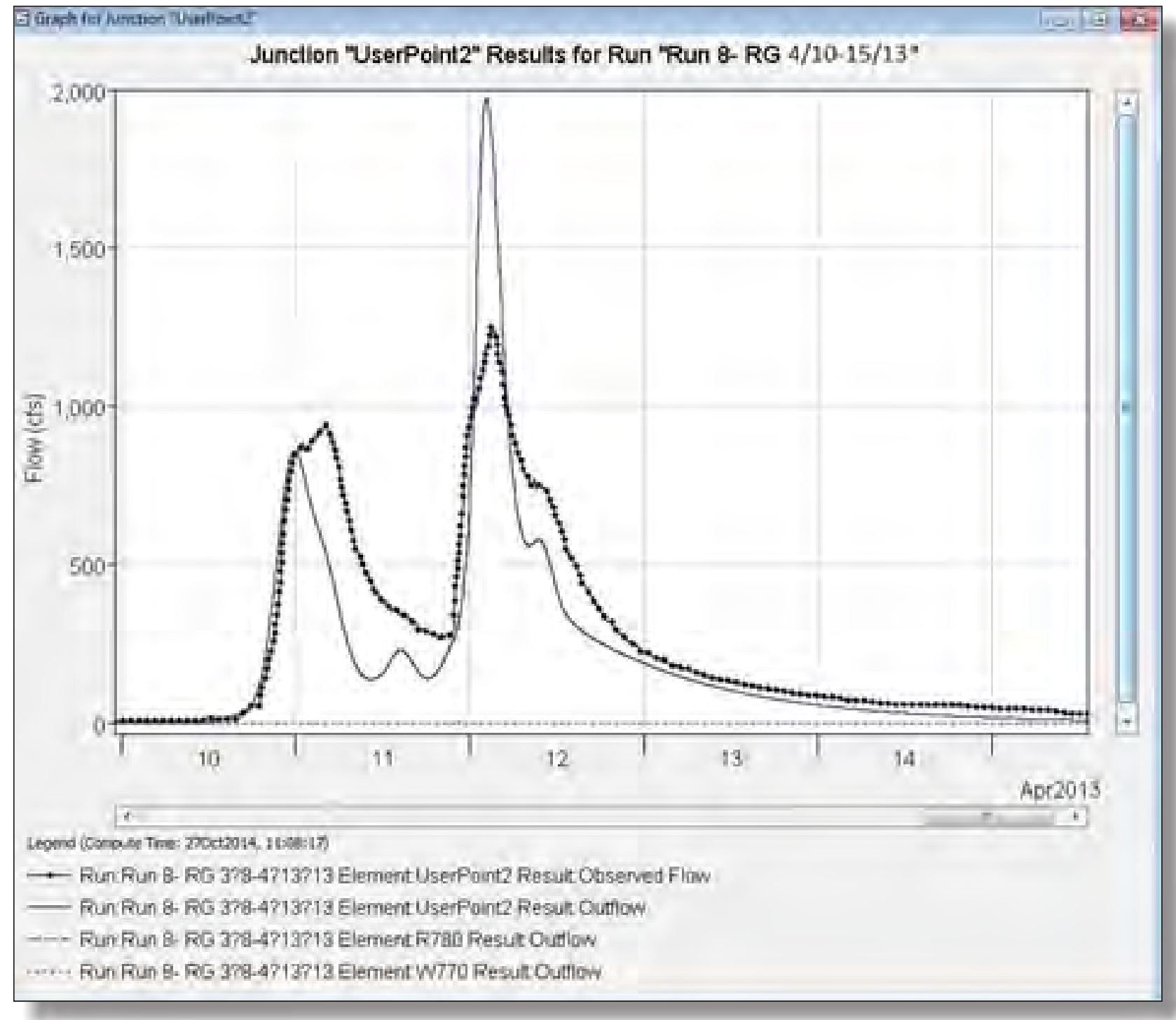

Figure 3-6. Plot from the HEC-HMS precipitation-runoff model, run 8, showing observed and simulated streamflows at the Black Fork Mohican River at Shelby, Ohio (U.S. Geological Survey streamflow-gaging station 03129197), during April 10-15, 2013. 
during the second peak on April 12, 2013, when the simulated peak flow was 58 percent larger than the observed peak and streamflow rates and, once again, volumes were underestimated during the recession (fig. 3-6). The total residual runoff volume is underestimated in the simulation by $-1.53 \mathrm{in}$. and the Nash-Sutcliffe model efficiency coefficient was 0.737 (table 5).

The June 13, 2013, event resulted in an observed peak stage of $12.67 \mathrm{ft}(1,077.97 \mathrm{ft}$ NAVD 88) at 07:15 EDT with an associated discharge of $1,440 \mathrm{ft}^{3} / \mathrm{s}$ at streamflow-gaging station 03129197 (fig. 3-7). The HEC-HMS simulation (model run 9) was begun on May 16 and continued through June 16. The precipitation gage (405209082393200) registered 2.23 in. of rainfall between June 10 at 07:00 EDT and June 13 at 03:45 EDT. In contrast to the conditions leading up to the April events, the area around Shelby had seen a considerable amount of rain prior to the June 13th event; according to the monthly water inventory report, June 2013 was the eleventh wettest out of the 131 years of record for the state as a whole (Kirk, 2013a). Figure 3-7 shows the observed and simulated streamflows at streamflow-gaging station 03129197 (UserPoint2, in HEC-HMS) for the June 12-15, 2013, period. Overall, the simulated event matched up well to the observed data, and model run 9 had the highest Nash-Sutcliffe model efficiency coefficient -0.899 - and the lowest residual runoff of -0.27 in. (table 5).

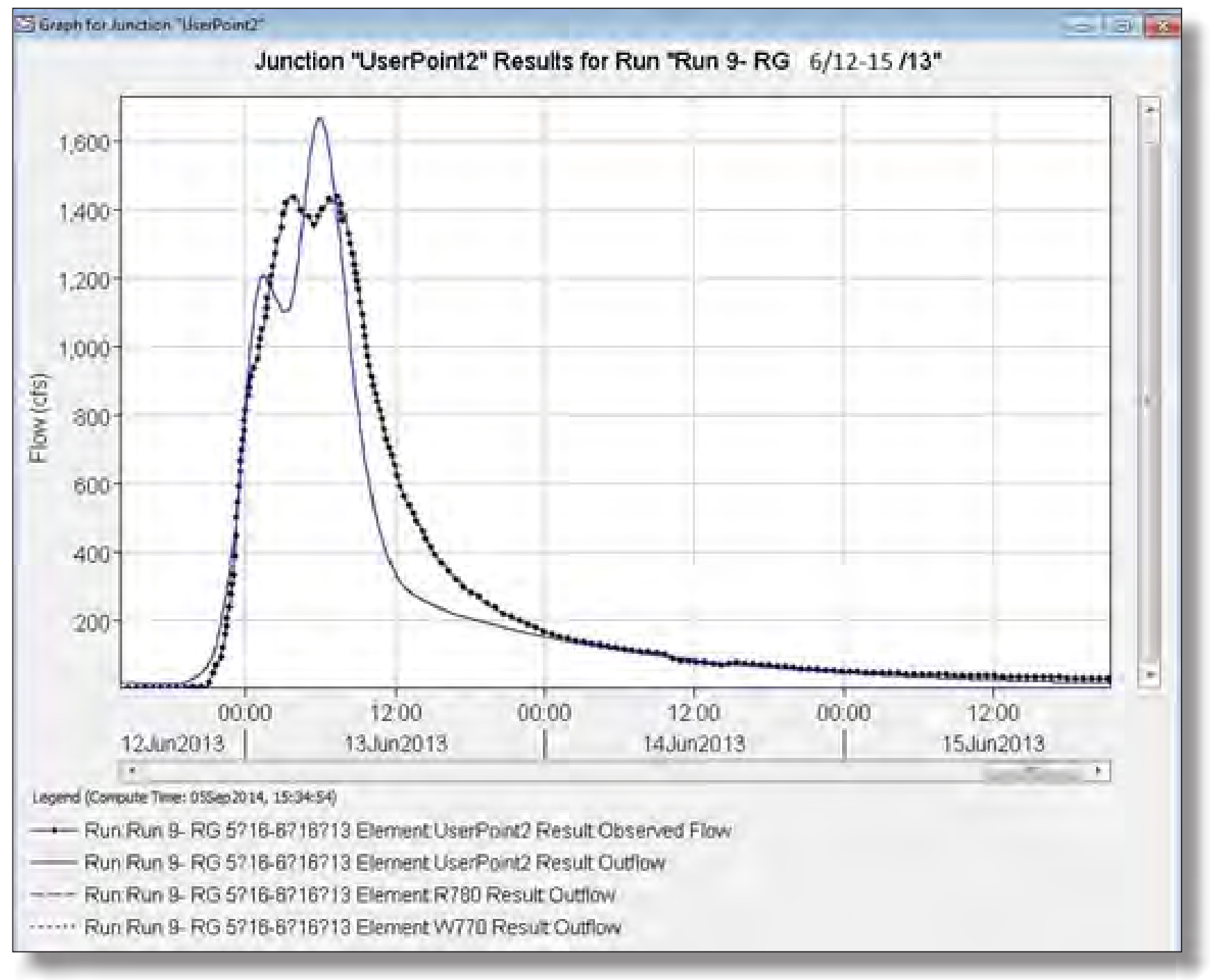

Figure 3-7. Plot from the HEC-HMS precipitation-runoff model, run 9, showing observed and simulated streamflows at the Black Fork Mohican River at Shelby, Ohio (U.S. Geological Survey streamflow-gaging station 03129197) during June 12-15, 2013. 
The largest peak streamflow event during the study occurred on July 9, 2013, and that was simulated in model run 10. During that event, streamflow-gaging station 03129197 malfunctioned from a suspected lighting strike during the period of peak flow, but a peak gage height of $19.05 \mathrm{ft}$ $(1,084.35$ NAVD 88$)$ was measured from the crest-stage gage, and the water level was verified through a survey of high-water marks (HWMs) found near the stream gage. The precipitation gage (405209082393200) recorded 1.72 in. of rain on July 8 , including $1.63 \mathrm{in}$. that fell in the 2 hours from 18:30 to 20:30 EDT. An additional $2.25 \mathrm{in}$. of rain fell on July 9 when the peak flow occurred at the stream gage; a total of 5.12 in. of rain fell from July 8 to July 10 . Antecedent conditions in the study area were already saturated due to a wet June and July, and July 2013 ranked as the fourth wettest for the state in 131 years of record (Kirk, 2013a, b). Figure 3-8 shows the cumulative precipitation at the precipitation gage (405209082393200) for July 4-12, 2013.
The July 9, 2013, event peak was estimated to occur at about 09:00 EDT. The peak gage height of $19.05 \mathrm{ft}(1,084.35$ $\mathrm{ft}$ NAVD 88) measured from the crest-stage gage, had an associated discharge of $4,130 \mathrm{ft}^{3} / \mathrm{s}$. Due to the streamgage malfunction, data were missing on July 9. Because HEC-HMS does not tolerate missing data, observed data in 15-minute time steps needed to be manually entered for the missing period. The observed data entered were based on USGS-approved gage heights and discharges. Data entered into HEC-HMS for July 9, 2013, were based on peak gage height (from the crest-stage gage) and the associated discharge and instantaneous streamflow measurements - numbers 18-21 - obtained during the recession of the hydrograph (table 3-3). Figure 3-9 shows output from the HEC-HMS model for July 7-12, 2013, at stream gage 03129197 (UserPoint2). The observed data were inserted into the model as follows: the estimated peak flow $\left(4,130 \mathrm{ft}^{3} / \mathrm{s}\right)$ was entered on July 9 at 00:00 EDT (labeled A on fig. 3-9) and repeated until

\section{RUSES}

\section{USGS 405209082393200 Rain Gage at Reservoir Number Two at Shelby OH}

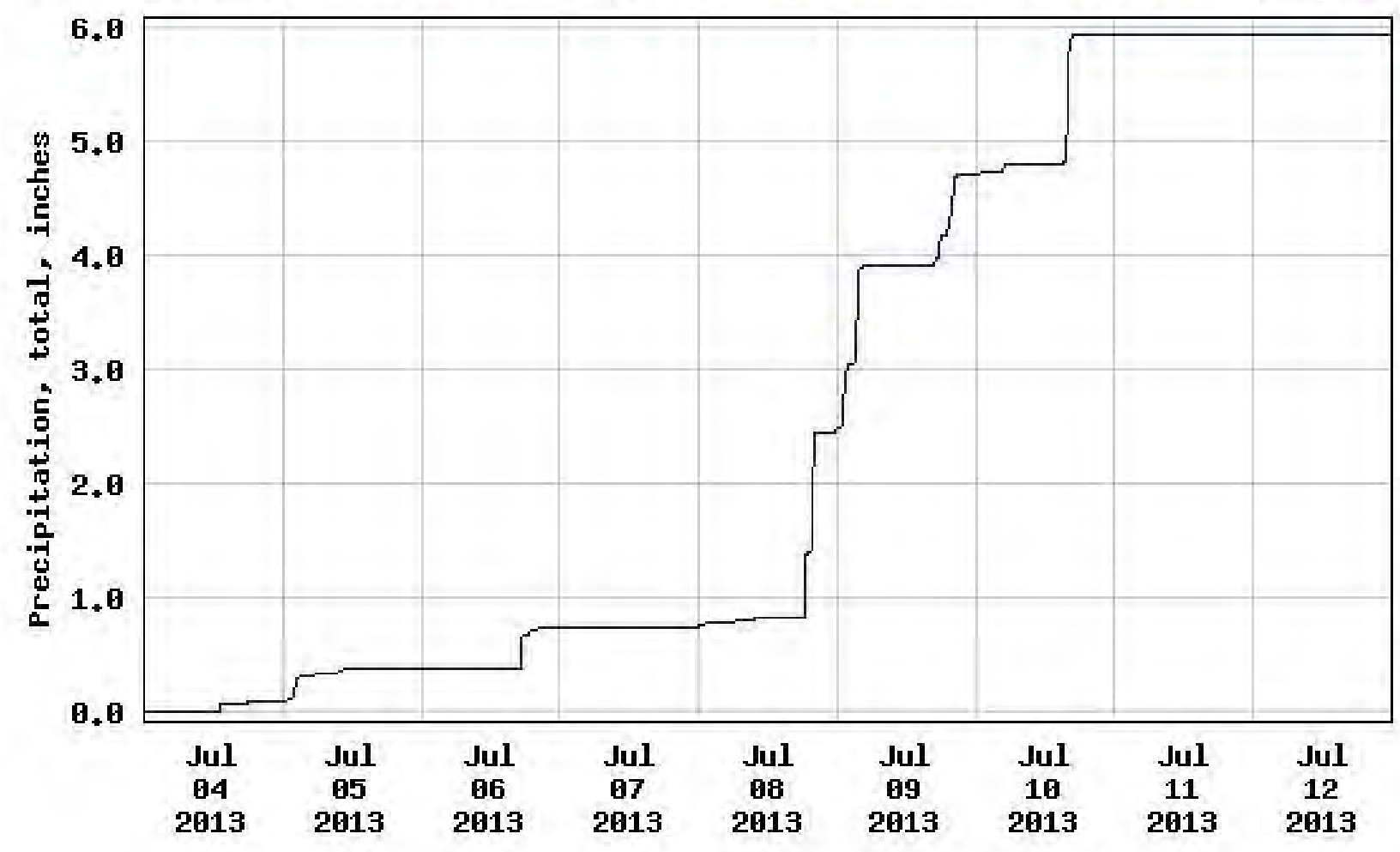

Figure 3-8. Plot showing the cumulative precipitation observed at the U.S. Geological Survey precipitation gage at Reservoir Number Two, at Shelby, Ohio (405209082393200), during July 4-12, 2013. 
Table 3-3. Instantaneous streamflow measurements taken at Black Fork Mohican River at Shelby,

Ohio (U.S. Geological Survey streamflow-gaging station 03129197), on July 9, 2013, during the recession of the hydrograph.

[All times listed are in Eastern Daylight Time, (EDT); $\mathrm{ft}^{3} / \mathrm{sec}$, cubic feet per second; $\mathrm{ft}$, feet, and NAVD 88 is the vertical coordinate information, North American Vertical Datum of 1988]

\begin{tabular}{|c|c|c|c|c|c|}
\hline $\begin{array}{c}\text { Measurement } \\
\text { number }^{1}\end{array}$ & $\begin{array}{l}\text { EDT-time at } \\
\text { streamgage }\end{array}$ & $\begin{array}{c}\text { HEC-HMS } \\
\text { time }^{2}\end{array}$ & Discharge $\left(\mathrm{ft}^{3} / \mathrm{s}\right)$ & Gage Height (ft) & $\begin{array}{c}\text { Stage } \\
\text { (ft NAVD 88) }\end{array}$ \\
\hline 18 & $13: 03$ & $13: 00$ & 1,550 & 13.25 & $1,078.6$ \\
\hline 19 & $13: 19$ & $13: 15$ & 1,500 & 12.94 & $1,078.2$ \\
\hline 20 & $13: 37$ & $13: 30$ & 1,420 & 12.50 & $1,077.8$ \\
\hline 21 & $13: 53$ & $13: 45$ & 1,350 & 12.12 & $1,077.4$ \\
\hline
\end{tabular}

${ }^{1}$ Measurement number is the order of the field discharge measurement number.

${ }^{2}$ HEC-HMS time is the closest 15 -minute time interval the observed data was time stamped in the precipiation runoff model.

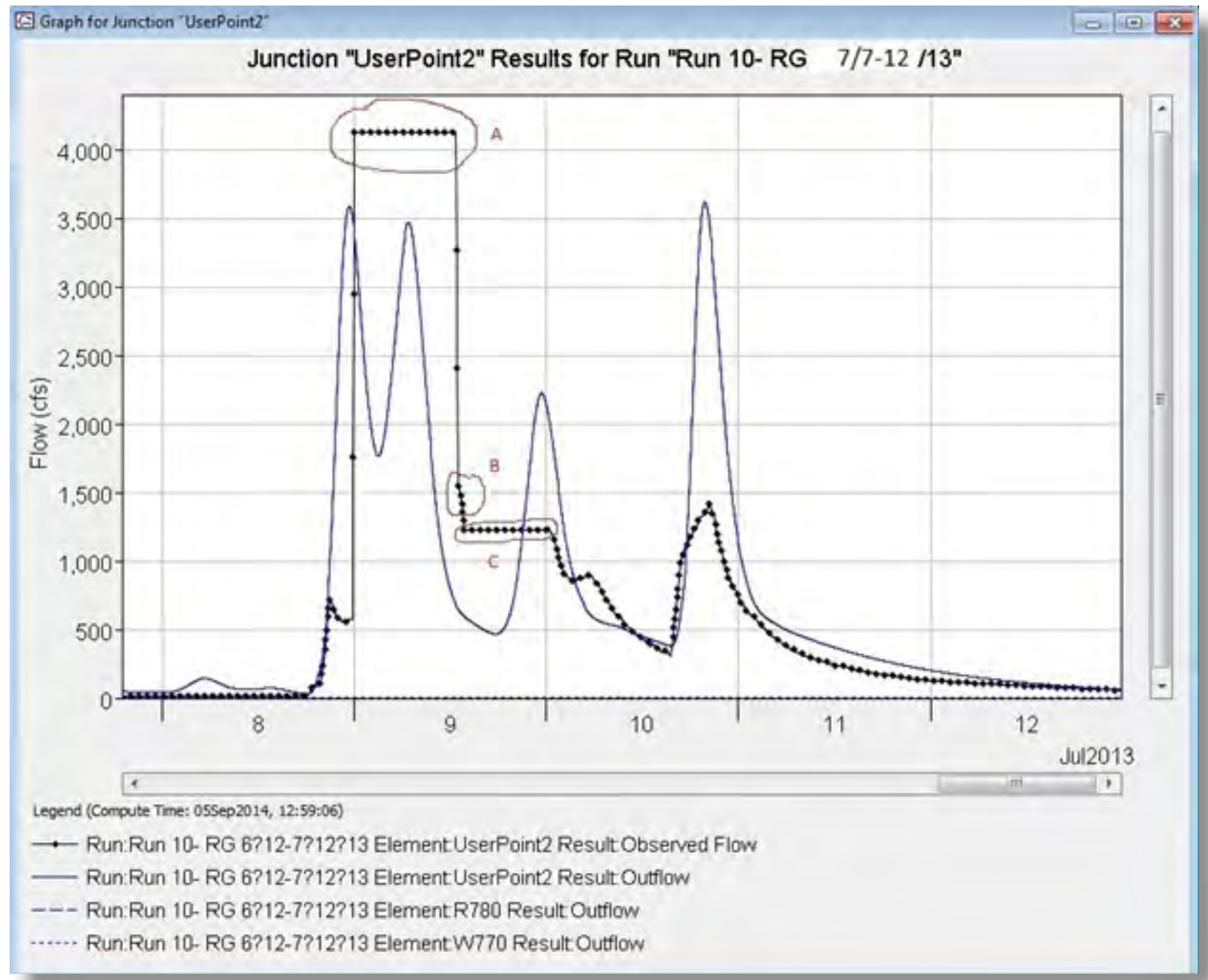

Figure 3-9. Plot from HEC-HMS precipitation-runoff model, run 10, showing observed and simulated streamflows at the Black Fork Mohican River at Shelby, Ohio (U.S. Geological Survey streamflow-gaging station 03129197) during July 7-12, 2013. 
the first instantaneous streamflow measurement was made at 13:03 EDT; then the four instantaneous streamflow measurements (labeled B on fig. 3-9); and finally the first approved streamflow value from the gage data (on July 10 at 00:00 EDT) was repeated backward in time until 14:00 EDT on July 9, 2013 (labeled C on fig. 3-9). Due to the lack of observed data on the day of the peak event and the possible inaccuracy of the simulated values, run 10 had the lowest Nash-Sutcliffe model efficiency coefficient of 0.544 ; however, the simulated residual runoff volume only underestimated by 0.69 in.

The first winter-period event, on December 22, 2013, resulted in a peak gage height of $13.65 \mathrm{ft}(1,078.95 \mathrm{ft}$ NAVD 88 ) at 06:15 EDT with an associated discharge of $1,750 \mathrm{ft}^{3} / \mathrm{s}$ at streamflow-gaging station 03129197. The HEC-HMS simulation (model run 11) was begun on December 3 and continued through December 26. Climate data obtained from the Mansfield airport indicated that approximately 5 in. of snowpack were on the ground from snow that fell during December 11-17. This was followed by six consecutive days (December 18-23) with temperatures at $32^{\circ} \mathrm{F}$ or above when some heavy rain fell. Data from the precipitation gage 405209082393200 indicated that $2.89 \mathrm{in}$. of rainfall precipitation fell in a 29-hour period during December 21-22. Table 3-4 shows precipitation and temperature data obtained at the Mansfield airport.

Figure 3-10 shows output from the HEC-HMS model for December 20-26, 2013, at USGS streamflow-gaging station 03129197 (UserPoint2). The simulated peak of this event was

Table 3-4. Precipitation and temperature data obtained at the Mansfield, Ohio airport (MFD) from December 18-23, 2013.

$\left[{ }^{\circ} \mathrm{F}\right.$, degrees Fahrenheit $]$

\begin{tabular}{cccc}
\hline Date & $\begin{array}{c}\text { Temperature } \\
\text { maximum }\left({ }^{\circ} \mathrm{F}\right)\end{array}$ & $\begin{array}{c}\text { Snow } \\
\text { (inches) }\end{array}$ & $\begin{array}{c}\text { Precipitation } \\
\text { (water } \\
\text { equivalent) } \\
\text { (inches) }\end{array}$ \\
\hline $12 / 18 / 2013$ & 32 & 0.0 & 0 \\
$12 / 19 / 2013$ & 46 & 0.0 & 0 \\
$12 / 20 / 2013$ & 56 & 0.0 & 0.12 \\
$12 / 21 / 2013$ & 62 & 0.0 & 2.09 \\
$12 / 22 / 2013$ & 59 & 0.0 & 0.67 \\
$12 / 23 / 2013$ & 37 & Trace & 0.01 \\
\hline
\end{tabular}

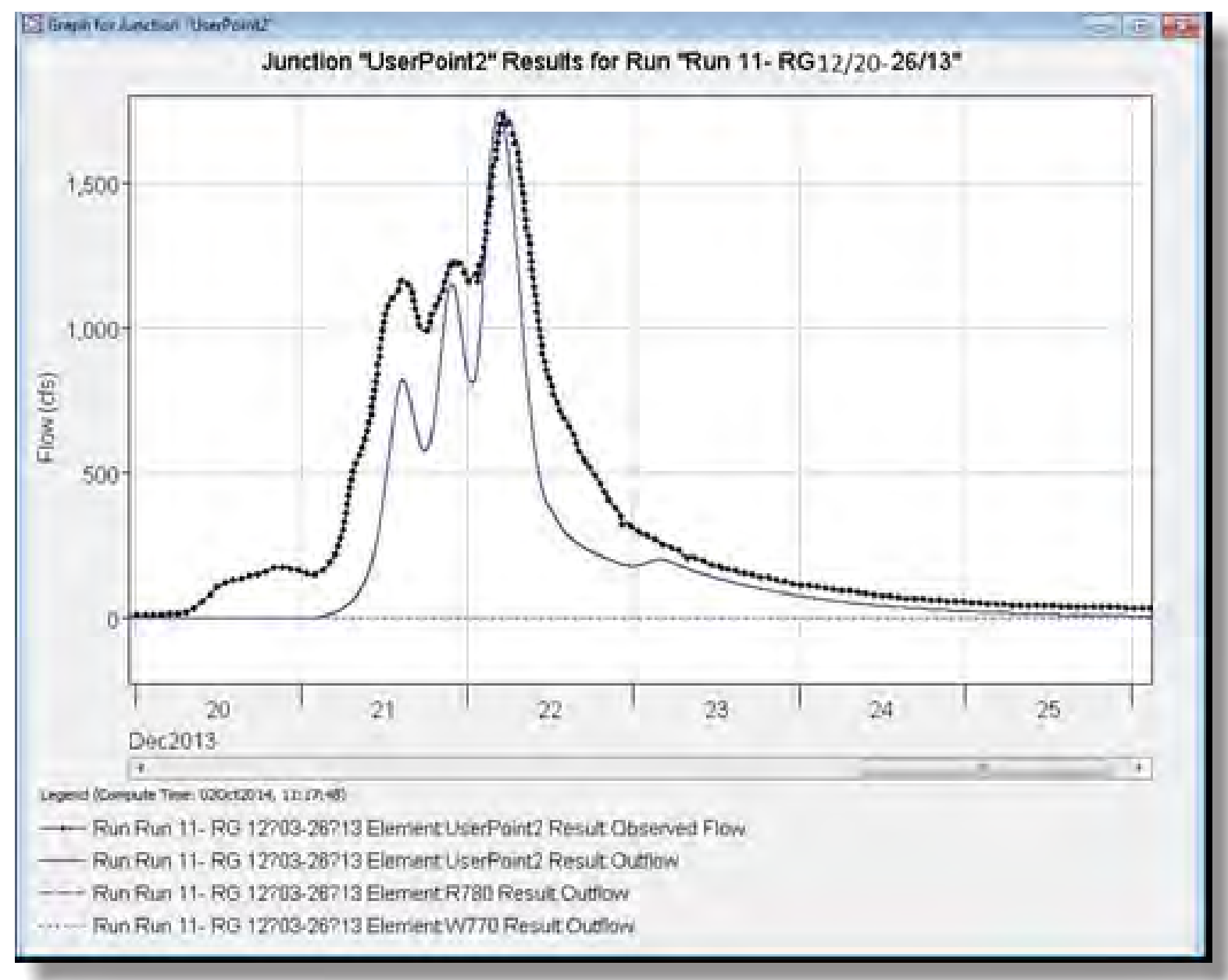

Figure 3-10. Plot from HEC-HMS precipitation-runoff model, run 11, showing observed and simulated streamflows at the Black Fork Mohican River at Shelby, Ohio (U.S. Geological Survey streamflow-gaging station 03129197) during December 20-26, 2013. 
within 0.6 percent of the observed data and had a Nash-Sutcliffe model efficiency coefficient of 0.850 , but the simulation still underestimated the runoff volume, and the residual runoff volume was -1.22 in. (table 5).

The second winter-period event, on February 21, 2014 , resulted in a peak gage height of $14.50 \mathrm{ft}(1,079.8 \mathrm{ft}$ NAVD 88) at 06:45 EDT with an associated discharge of $2,040 \mathrm{ft}^{3} / \mathrm{s}$. The HEC-HMS simulation (model run 12) began on February 1 and continued through February 26. Climate data obtained at the Mansfield airport indicated that temperatures ranged from -6 to $39^{\circ} \mathrm{F}$, and approximately 8 in. of snow accumulated during the period February 2-16, 2014. Temperatures began to warm - ranging from 34 to $56^{\circ} \mathrm{F}$ - during the period of February 17-21, 2014, when snowfall changed to rain (table 3-5).

Data from the precipitation gage 405209082393200 indicated that 0.77 in. of precipitation fell in 18 hours during February 20-21. Figure 3-11 shows the HEC-HMS model output from February 20-22 at streamflow gaging station 03129197
(UserPoint2). This event simulated the peak within 7 percent of the observed data and had a Nash-Sutcliffe model efficiency coefficient of 0.671 ; runoff volume was underestimated, because the residual runoff volume was -1.52 in. (table 5 ).

Table 3-5. Precipitation and temperature data obtained at the Mansfield, Ohio airport (MFD) from February 17-21, 2014.

[ ${ }^{\circ} \mathrm{F}$, degrees Fahrenheit]

\begin{tabular}{cccc}
\hline Date & $\begin{array}{c}\text { Temperature } \\
\text { maximum ('F) }\end{array}$ & $\begin{array}{c}\text { Snow } \\
\text { (inches) }\end{array}$ & $\begin{array}{c}\text { Precipitation } \\
\text { (water equivalent) } \\
\text { (inches) }\end{array}$ \\
\hline $2 / 17 / 2014$ & 34 & 2.2 & 0.18 \\
$2 / 18 / 2014$ & 43 & 0.5 & 0.05 \\
$2 / 19 / 2014$ & 48 & 0.0 & 0.00 \\
$2 / 20 / 2014$ & 56 & 0.0 & 0.20 \\
$2 / 21 / 2014$ & 55 & 0.0 & 0.48 \\
\hline
\end{tabular}

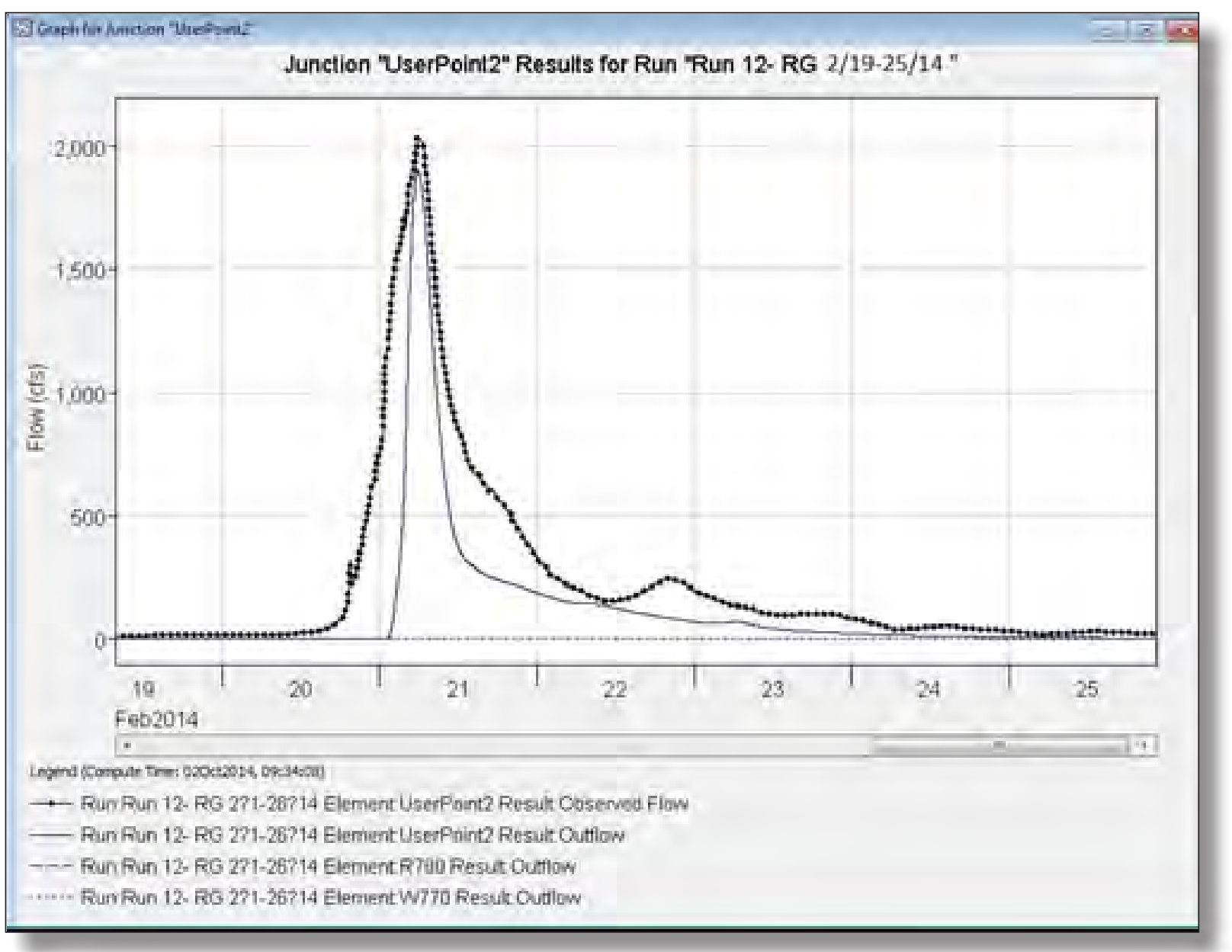

Figure 3-11. Plot from HEC-HMS precipitation-runoff model, run 12, showing observed and simulated streamflows at the Black Fork Mohican River at Shelby, Ohio (U.S. Geological Survey streamflow-gaging station 03129197) during February 19-25, 2014. 


